\title{
Proceedings of the Workshop on
}

\section{Recent Innovations and New Twists in Small Fruit Crop Production}

\author{
sponsored by \\ the ASHS \\ Viticulture and Small Fruit \\ Working Group \\ presented at \\ ASHS-97 \\ 22-26 July 1997 \\ Salt Lake City, Utah
}




\section{Introduction to the Workshop}

W. Alan Erb

$\mathrm{T}$

his workshop presents information on some alternative production systems for certain small fruit crops. The small fruit classification is almost a misnomer, because it is not the size of the fruit that puts different plantsinto thiscategory, it isthesize of the plant. Small fruit areherbaceous perennial or woody perennial shrubs, vines, and brambles. This group of plants is large and diverse. Some common small fruit are grapes, strawberries, blackberries, raspberries, and blueberries. Because there is such a variety of different plant types in this diverse group, each member of this array has its own special production needs. In addition, small fruit crops are of high value and either harvested for the fresh market or for processing. Production practices can range from highly mechanized field systemsto labor-intensivegreenhouse practices. Theinformation presented in this workshop is new and exciting, and all the production systems discussed offer growers ways to increase the value of their small fruit crops.

Thisworkshop waspart of the 1997 ASH Sannual conferencein Salt L akeC ity, U tah, and it originally contained presentations on the following topics: a new plasticulture production system for strawberry varieties developed for the eastern U nited States, a vertical greenhouse strawberry production system, a red raspberry greenhouse production system, atotal mechanization system for grape production, a more-efficient trellis system for fresh-market blackberry production, and a new mechanical harvester capable of harvesting blackberries for the fresh market. The first two presentations listed are not included in this published account of the workshop. H owever, information on plasticulture strawberry production is available ( $\mathrm{H}$ andley, 1998), and a publication on vertical greenhouse strawberry production is also accessible (C arpenter, 1996). The manuscript on grape mechanization (M orris, 1999) has been expanded to also include information on mechanized systems for brambles and strawberries. The last two presentations on blackberries were combined because the new blackberry harvester was specifically designed to remove fruit from blackberry plants trained to the new trellis system (Takeda and Peterson, 1999).

The three papers of this proceedings provide horticulturists with information on innovativeand creative production technologies. This material should stimulate higher-valued small fruit production and more research and development on these or other production systems.

\section{Literature cited}

Carpenter, T.D. 1996. Greenhouse strawberry production reaches new heights. Greenhouse M gt. \& Prod. (September):38-43.

H andley, D. 1998. Production systems, p. 18-27. In: M. Pritts and D. H andley (eds.). Strawberry production guide. NE Reg. Agr. Eng. Serv., I thaca, N.Y.

Morris, J.R. 1999. Developing mechanized systems for production, harvesting, and handling brambles, strawberries, and grapes. H ortT echnology 9:22-31.

Takeda, F. and D.L. Peterson. 1999. Considerationsfor machine harvesting eastern thornless blackberry for fresh market: T rellis design, cane training system, and mechanical harvester development. $\mathrm{H}$ ortT echnology 9:16-21.
Pair H orticultural Center, $1901 \mathrm{E}$.

95th Street South, $\mathrm{H}$ aysville, KS 67060 . 


\section{Winter Raspberry Production in Greenhouses}

M arvin P. Pritts, Robert W. Langhans, Thomas H. Whitlow, M ary J o Kelly, and Aimee Roberts

Additional index words. Bombusimpatiens, bumble bees, $R$ ubusidaeus

Summary. Floricane-fruiting (summer-bearing) raspberries (R ubusidaeusL .) were grown outdoors in pots in upstate $\mathrm{N}$ ew York until mid-D ecember when the chilling requirement was fulfilled. They were moved into a greenhouse and placed at a density that is three times higher than field planting. B umble bees (Bombusi mpatiens C resson) were introduced at flowering for pollination. Fruiting occurred from mid-February through mid-A pril, a time when the retail price for raspberries is between $\$ 3.00$ and $\$ 6.00$ for a half pint (180 g). Fruit quality was high, and individual 2-year-old plants averaged 11 half pints $(2 \mathrm{~kg})$ of marketable fruit. These yields and retail prices are equivalent to $19,000 \mathrm{lb}$ and $\$ 142,000$ per acre (21 t, $\$ 350,000$ per ha). $R$ aspberry production during winter allows growers to dramatically extend the harvest season and to produce a high-value crop at a time when greenhouses often are empty.

$\mathrm{n}$ N orth America, greenhouse production of edible products has been limited primarily to tomatoes, cucumbers, greens, and herbs, while food retailers have relied on imports to supply fruit during the off season. In many cases, the quality of this imported fruit is poor. We have been exploring the possibility of producing various fruit crops year-round for local markets to meet consumer demand for consistently flavorful fruit harvested when fully ripe.

Raspberries are uniquely suited for year-round production. The two growth habits allow for field production in the summer (floricane-fruiting types: bearing fruit only on second-year canes from late J une through early August) and early fall (primocane-fruiting types: bearing fruit on first-year canes in late August and September). H owever, potted primocane-fruiting types fruit in late fall and early winter if plants are held in cold storage until early J uly, and floricane-fruiting types can produce during late winter and early spring if potted plants are brought into a greenhouse after their chilling requirement is fulfilled in early winter. This paper describes one method used successfully to produce raspberries during February through April in N ew York.

Raspberries are a high value crop that retail for $\$ 3.00$ to $\$ 6.00$ per half pint $(180 \mathrm{~g}$ ) during the winter and early spring throughout $\mathrm{N}$ orth America. No domestic sources of winter raspberries exist, except a few producers in a small region in southern California along the coast. 
M ost winter raspberriesareflown in from the southern hemisphere. Q uality is often poor because raspberries have an extremely short postharvest life and bruise easily during shipping.

In thenortheastern U nited States, many greenhouses are empty during the winter. These greenhouses could be used to grow high-quality raspberries with only moderate inputs, providing greenhouse owners with an opportunity to produce an extremely high-value crop during a time of the year when they are realizing no return on their capital investment. I n our first attempt at growing greenhouse raspberries, we obtained the equivalent of $\$ 2,000$ to $\$ 4,000$ (660 half pints) of exceptionally high-quality fruit from $100 \mathrm{ft}$ ( $30 \mathrm{~m}$ ) of row (60 two-year-old plants of 'C hilliwack') in a $20 \times 30-\mathrm{ft}$ $(6 \times 9-m)$ house between mid-February and mid-A pril. This is $>17,500 \mathrm{lb} /$ acre $\left(20 \mathrm{t} \cdot h \mathrm{a}^{-1}\right)$, about four times more than what growers obtain from field production in thenortheastern $U$ nited States. In addition, by holding dormant raspberry plants in cold storage during the winter and bringing them into the greenhouse at staggered intervals, they can be made to ripen for several months before and up to the normal raspberry season, dramatically extending the season of availability.

Raspberriesappear to beuniquely suited to winter greenhouse production. Raspberry plants can produce a crop under low light, and the maximum photosynthetic rate occurs at relatively cool temperatures (Fernandez and Pritts, 1994). O ff-season raspberry production has been attempted in mild growing areas of E uropewhere primocane-fruiting types are mowed in spring to delay fruiting into autumn (O liveira et al., 1996), and Europeans are beginning to explore winter production of floricane-fruiting types in greenhouses (D ijkstra and Scholtens, 1993). H owever, commercial enterprises are only now beginning to develop.

Raspberry flowers require pollination to set fruit, so a successful greenhouse production system must ensure adequatepollination. Bumblebeehives are now commercially available, and bumble bees appear to be superior pollinatorsto honey bees in the greenhouse. In addition, biological control agents have been developed recently to manage greenhouse pests, making pesticide sprays unnecessary and allowing the bumble bee pollinators to thrive. Several factors are now in place that can make winter raspberry production successful: high pricesfor fruit, empty greenhouses throughout the continent during winter, domesticated bumble bees, and effective biological control. In addition, with deregulation of electric power, costsfor heating and lighting should decrease while the cost of fuel for transportation is likely to rise. These changing economic conditions are favorable for local off-season and year-round fruit and vegetable production.

\section{Procedure}

We planted several cultivars of summer-bearing (floricane-fruiting) tissue-cultured raspberry plugs into 1gal (3.8-L) pots filled with equal parts sand, peat, perlite, and vermiculite in $M$ ay, allowed them to grow outdoors on a gravel bed with irrigation until late December, then brought them into the greenhouse. While outdoors, plants were fertilized weekly with a mixture of a soluble fertilizer (Peter's $\mathrm{H}$ ydrosol, 5-11-26), ammonium nitrate and calcium nitrate to obtain 100 ppm N , and pest outbreaks were managed using conventional practices. Once in the greenhouse, canes were trellised and watered with the same fertilizer solution. $\mathrm{H}$ ousehold fanswere used to circulate air down the rows to reduce pockets of high humidity and the subsequent risk of fungal infection. Temperatures were maintained between 55 to $65^{\circ} \mathrm{F}$ ( 13 to $18^{\circ} \mathrm{C}$ ). Supplemental light was provided to first-year plants during off-peak hours [ 2200 to $0600 \mathrm{HR}, 150 \mu \mathrm{mol} \cdot \mathrm{m}^{-2} \cdot \mathrm{s}^{-1}$ of photosynthetically active radiation (PAR)].

Six to eight weeks after plants were moved into the greenhouse, they flowered. Bumble bees were used to pollinate the flowers, and fruiting began in late February, $\approx 10$ weeks after moving the plantsindoors. Primocanes were removed at regular intervals during the fruiting period.

With the1-year-old plants, weused double rows [ with row centers $5 \mathrm{ft}$ ( 1.5 $\mathrm{m})$ apart] and a pot-to-pot spacing so that 70 plantswerecontained in each 26 $\mathrm{ft}(8 \mathrm{~m})$ length of row. Each plant produced $\approx 1$ pint ( $350 \mathrm{~g}$ ) of fruit.

We removed all of the canes after harvest, and transplanted into 7-gal (26.5-L) potsfor thesecond year. Plants were placed outside for the growing season after harvest in A pril, and they were returned to the greenhouse in mid-D ecember after the chilling requirement had been fulfilled. Rapidly satisfying the chilling requirement is one advantage that northern growers have over more southern producers. O utdoors, plants were watered regularly and fertilized once a week with a soluble fertilizer solution (100 ppm $\mathrm{N})$. C anes were held upright with trellises as they grew and were exposed to full sun.

In the second year in the greenhouse, we spaced plants 22 inches ( 55 $\mathrm{cm}$ ) apart in the row (single rows), with $5.5 \mathrm{ft}(1.7 \mathrm{~m})$ between rows. This density is three times that of standard field plantings. During 1997, we examined the performance of several varieties and evaluated two trellis configurations (an I and V trellis) and three light levels (ambient PAR ranging from 1 to 10 , a constant 7.5 and a constant $15 \mathrm{~mol} \cdot \mathrm{m}^{-2} \cdot \mathrm{d}^{-1}$ ) in the 2year-old plants. Light levelswere measured $6.5 \mathrm{ft}(2 \mathrm{~m})$ above the floor, and supplemental light was provided when required to meet the predetermined level of 7.5 or $15 \mathrm{~mol} \cdot \mathrm{m}^{-2} \cdot \mathrm{d}^{-1}$. (O n a cloudy January day, PAR can be $<1$ $\mathrm{mol} \cdot \mathrm{m}^{-2} \cdot \mathrm{d}^{-1}$; on a sunny day in July, PAR can be $\left.>30 \mathrm{~mol} \cdot \mathrm{m}^{-2} \cdot \mathrm{d}^{-1}\right)$. Bumble bees were again used for pollination.

\section{Cultivar performance}

We fruited a number of cultivars over the 2-year period. Furthermore, weinvited chefs and produce buyers to a blind tasting, where our fruit was compared with 'H eritage' purchased from two local supermarkets. Thecultivar with the most desirable flavor was 'Tulameen', followed by 'C anby', 'Encore', and 'C hilliwack'. O ther cultivars with acceptable flavor included 'M alahat', 'Q ualicum', and 'L auren'. 'Titan' also produced flavorful and extremely large fruit. E arly in the season, 'Titan' fruit size averaged $6 \mathrm{~g}$ (some berrieswere $12 \mathrm{~g}$ ) and fell to $3 \mathrm{~g}$ over the 8-week harvest period. 'C hilliwack' produced an average of 11 half-pints $(2 \mathrm{~kg}$ ) of fruit per plant between $18 \mathrm{Feb}$. and 18 Apr. Fruit flavor was very good, although thesizewassmaller than with some of the other cultivars, and the color was darker. Of all the red raspberry cultivars that we evaluated, 'Tulameen' was rated as having the highest quality, while the supermarket entries ranked lowest. 
'Jewel' black raspberry also produced excellent large fruit, but yields were $\approx 70 \%$ lower than those of the red raspberries because the harvest season was much shorter ( 6 vs. 9 weeks).

Compared to field production, the greenhouse-produced berrieswere larger, firmer, and much less prone to fruit rot. 0 nly $6 \%$ of the greenhouse berries were crumbly or otherwise unmarketable, whereas the percentage of field-grown berries that are unmarketable is usually much higher. Fruit tended to be slightly less sweet and more acid in the greenhouse, but well within the limits of acceptability. O nly 'Royalty' purple raspberry and 'Autumn Bliss' and ' $\mathrm{H}$ eritage' red raspberry (floricane crop) did not produce fruit of acceptable flavor.

Wesuspect that ' $T$ itan' hasalonger chilling requirement than 'T ulameen' or 'Chilliwack', because only the top third of the canes produced flowering laterals. 'T itan' likelyneedsto bechilled beyond mid-D ecember in our climate. If plants are to be kept outdoors later than mid-D ecember in $\mathrm{N}$ ew York, then the pots must be protected from the cold weather. 0 therwise, plantscan be brought into a cooler in early $D$ ecember and the rest of their chilling requirement can be fulfilled there.

\section{Primocane management}

After harvest, weremoved all canes and set the plants outside in late A pril. $\mathrm{H}$ owever, certain varieties failed to regrow primocanes until very late in summer, including 'T ulameen', 'C hilliwack', and 'Encore'-our most productive varieties. We believe this may have been due to the large amount of crop that we produced in conjunction with primocane removal to facilitate harvest, depleting the carbohydrate reserves. Fernandez and Pritts (1993, 1994) have shown that primocanes are the primary source for root carbohy- drate, so it is not surprising that continual primocane removal will deplete reserves. In the future, we will retain some of the primocanes during the fruiting season so they can replenish root reserves. If we do this, plants will have to bekept in thegreenhouse until the danger of heavy frost is over in spring so primocanes are not injured.

\section{Light levels}

Supplemental lighting had no effect on either fruit size or number of 'Titan' or 'J ewel' under our specific conditions. Plantsgrown under ambient light produced the same yields as plants grown under $15 \mathrm{~mol} \cdot \mathrm{m}^{-2} \cdot \mathrm{d}^{-1}$, although fruiting under the ambient light level was delayed for 2 to 3 weeks. F ruiting lateralsunder low light conditions also tended to be quite long and would frequently break under the heavy fruit loads. H owever, quality (determined by flavor ratings and soluble solids measurements) was not different among light levels. The ability of raspberry plants to rely on stored carbohydratesto produceacrop under low light was documented in a previous study (Fernandez and Pritts, 1996).

Trellisconfiguration (I vs. V) also had little effect on yield, although it was more difficult to harvest $\mathrm{V}$-trellised plants, as they required a greater amount of space. Therefore, we will use a standard I configuration in future studies.

\section{Pests}

We regularly released $A$ mblysei us cucumerisO udemansto control thrips, lacewing larvae and A phidoletes aphi dimyza R ondani midgefor aphids, and Phytoseiulus persimilis Athias$\mathrm{H}$ enriot for mites. Our major pest problem wastwo-spotted spider mites (Tetranychus urticae Koch), which occurred in one house during the last
2 weeks of harvest. We hypothesize that a lower night temperature will reduce mite pressure.

\section{Economics}

At our orchard store, we sold raspberriesfor $\$ 3.00$ per half pint without consumer resistance, and the gross return per area [about $\$ 2.80$ to $\$ 3.70$ / $\mathrm{ft}^{2}\left(\$ 30.00\right.$ to $\left.\$ 40.00 / \mathrm{m}^{2}\right)$ for the 4month period] wassimilar to the return that local growerstypically receive from bedding plants. O ne bedding plant grower in the area is now producing raspberries to coincide with bedding plant season to increase customer purchases during A pril and $\mathrm{M}$ ay.

Raspberries are well suited to greenhouse production, and the economics appear to befavorable. We will learn much over the next few years as growers and researchers begin to experiment with this novel production system.

\section{Literature cited}

D ijkstra, J . and A. Scholtens. 1993. G rowing early and late raspberries in containers. Acta H ort. 352:49-54.

Fernandez, G.E. and M .P.Pritts. 1993.Growth and source-sink relationships in 'Titan' red raspberry. Acta H ort. 352:151-158.

Fernandez, G.F. and M .P. Pritts. 1994. Growth, carbon acquisition, and sourcesink relationships in 'T itan' red raspberry. J. Amer. Soc. H ort. Sci. 119:1163-1168.

Fernandez, G.E. and M.P. Pritts. 1996. Carbon supply reduction has a minimal influence on current year's red raspberry ( $R$ ubusidaeusL.) fruit production. J. Amer. Soc. H ort. Sci. 121:473-477.

Oliveira, P.B., C.M . O liveira, L. L opes-deFonseca, and A.A. M ontiero. 1996. O ffseason production of primocane fruiting red raspberry using summer pruning and polyethylenetunnels. H ortScience31:805-807. 


\title{
Considerations for Machine Harvesting Fresh-market Eastern Thornless Blackberries: Trellis Design, Cane Training Systems, and Mechanical Harvester Developments
}

Fumiomi T akeda and D onald L. Peterson ${ }^{2}$

\begin{abstract}
Additional index words. $R$ ubus, brambles, engineering, floricanes, fruit, management, primocanes, quality

Summary. There is increased interest in growing blackberries in the $U$ nited States for the fresh fruit market. For fresh market blackberry production, $>350 \mathrm{~h} /$ acre $\left(900 \mathrm{~h} \cdot \mathrm{ha}^{-1}\right)$ of work is required to hand pick blackberries over a season that lasts 5 weeks with harvest every 2 days. Existing bramble mechanical harvesters can detach fruit from plants trained on a vertically oriented I trellis and harvest more cheaply than when harvested by hand, but the harvested fruit does not have fresh-market quality. We developed a cane training and trellis system for semierect blackberries to orient canes horizontally with the fruit positioned below the canes. Also, we developed an over-the-row mechanical harvester that uses vibrating nylon rods on a drum to shake fruit from horizontally trained canes onto a moving fruit-catching surface directly under the canopy to minimize impact damage to fruit. A new trellis design, new cane training practices, and new harvesting technologies have allowed fruit to be removed efficiently and be acceptable for fresh-market sales. This production system has been evaluated economically and appears to be profitable. It could overcome the high cost of handpicking, which has limited the expansion of fresh-market blackberries.
\end{abstract}

$\mathrm{n}$ the last 30 years, the U .S. D epartment of Agriculture (USD A) has released seven semierect, genetically thornless blackberry cultivars: 'Black Satin', 'Smoothstem', 'Thornfree', 'D irksen Thornless', 'H ull Thornless', 'C hester Thornless', and 'Triple Crown'. These cultivars are characterized by vigorous, semierect, smooth canes, and high productivity (M oore and Skirvin, 1990). The latter two have large, firm fruit, improved fresh-market and processing qualities ( $\mathrm{H}$ alat et al., 1997), and are now commercially grown in states along the midAtlantic coast, in the M idwest, and along the Pacific coast.

The expansion of blackberry production into colder areas has been limited because of a lack of cold hardiness in existing cultivars (Warmund et al., 1992). These blackberries are produced mainly on small-acreage farms and hand picked for fresh-pack and pick-your-own markets.

U SD A-ARS, Appalachian Fruit Research Station, 45 Wiltshire Road, Kearneysville, WV 25430.

The cost of publishing this paper was defrayed in part by the payment of page charges. U nder postal regulations, this paper therefore must be hereby marked advertisement solely to indicate this fact.

${ }^{1}$ Research horticulturist.

${ }^{2}$ Agricultural engineer. 
Typically, theripefruit of semierect blackberries are harvested over a 5- to 6-week period at 2- to 4-d intervalsand can require as much as $350 \mathrm{~h} /$ acre $\left(900 \mathrm{~h} \cdot \mathrm{ha}^{-1}\right)$ of work if hand harvested (B rown et al., 1983). Scarcity of workers and the high cost of harvest labor have prevented increased commercialization of semierect blackberries. The L incoln canopy system (D unn et al., 1976), Gjerde method (O ydvin, 1986), slanted trellises (Peterson et al., 1992; Takeda and Peterson, 1996), and the variations of the shift trellis (Stiles, 1995) have positioned the fruiting zone of raspberries and blackberries to enable the fruit to be picked faster and to facilitate mechanical harvest operation.

M echanical harvesters have been develo ped to rapidly harvest large acreage of blackberriesfor processing ( $M$ artin and $L$ awrence, 1976). M achine-harvested blackberries are higher-quality fruit (larger fruit, higher percentage of total soluble solids, lower acidity, and superior color) than hand picked fruit (M orris et al., 1978). H owever, no blackberries have been machine harvested for freshmarket use (M oore and Skirvin, 1990), and harvesting by machine has been shown to reduce the amount of saleablefruit compared with hand picking (Kingston, 1991).

This paper presents research conducted at the Appalachian Fruit Research Station, Kearneysville, W.Va., to develop alternative cane-training practices, trellis designs, and a new mechanical harvesting concept for the semierect, eastern thornless blackberry cultivars. They could ultimately allow cheaper, highly mechanized operationsto harvest freshmarket-quality fruit.

\section{Training and pruning for machine harvesting}

Semierect blackberries are planted typically in rows spaced 10 to $12 \mathrm{ft}$ ( 3 to $3.6 \mathrm{~m}$ ) apart with plants set at 5 to $8 \mathrm{ft}$ ( 1.5 to $2.4 \mathrm{~m}$ ) apart in the row and maintained in a hill culture system. The plants have a semierect growth habit and must be supported by a trellis post-and-wire system. As the primocanes grow, lateral canes develop at the axils of leaves. To promote the growth of these lateral canes along the entire length of the cane, primocanes are tipped as they extend beyond the top trellis wire. The laterals that emerge at the base of primocanesaregenerallylarge and stiff and not amenable for hand manipulation. $\mathrm{H}$ owever, the few suckers that radiate from the crown parallel with the row direction may be left and trained to trellis wires for fruit production.

A successful machine-harvesting system must include a trellis design to shape the plant into a narrow, unobstructed fruiting canopy. This allows the shaking mechanism to be positioned into the plant and the fruitcatching surface to be placed just below the fruiting canopy where fruit will be damaged least. The common support system for eastern thornless blackberries has been the standard I system (Fig. 1a) consisting of post or stake $\approx 6.5$ $\mathrm{ft}(2-\mathrm{m})$ tall with two or more wires spaced evenly on the post. During the summer, as many as six strong primocanes are tied to these wires and tipped just above the top wire to promote lateral cane development. Additionally, all lateral soriginating near the ground and weak primocanes are removed. Following harvest, old floricanesaretypical ly cut off at ground level. In the winter, the laterals in the fruiting zoneare pruned to 20 inches $(0.5 \mathrm{~m})$ in length (Steiner et al., 1983).

Although the standard I system is relatively cheap, our early work indicated that the lateral canes were damaged considerably and fruit were bruised excessively during the harvest-and-catch operation (Takeda et al., 1989). Sincethelateral canes were not tied to the trellis wires, the energy transmitted from the harvester rod action to individual fruit was not sufficient to detach many berries. Also, we observed that lateral cane and fruiting lateral numbers were low in the middle portion of the trellis because there was insufficient light for axillary bud development.

\section{Trellis designs}

At the Appalachian Fruit Research Station, we evaluated several trellis designs that expanded the canopy surface to increase yield and makethefruit moreaccessible for picking (Takeda et al., 1989). In all of the trellis

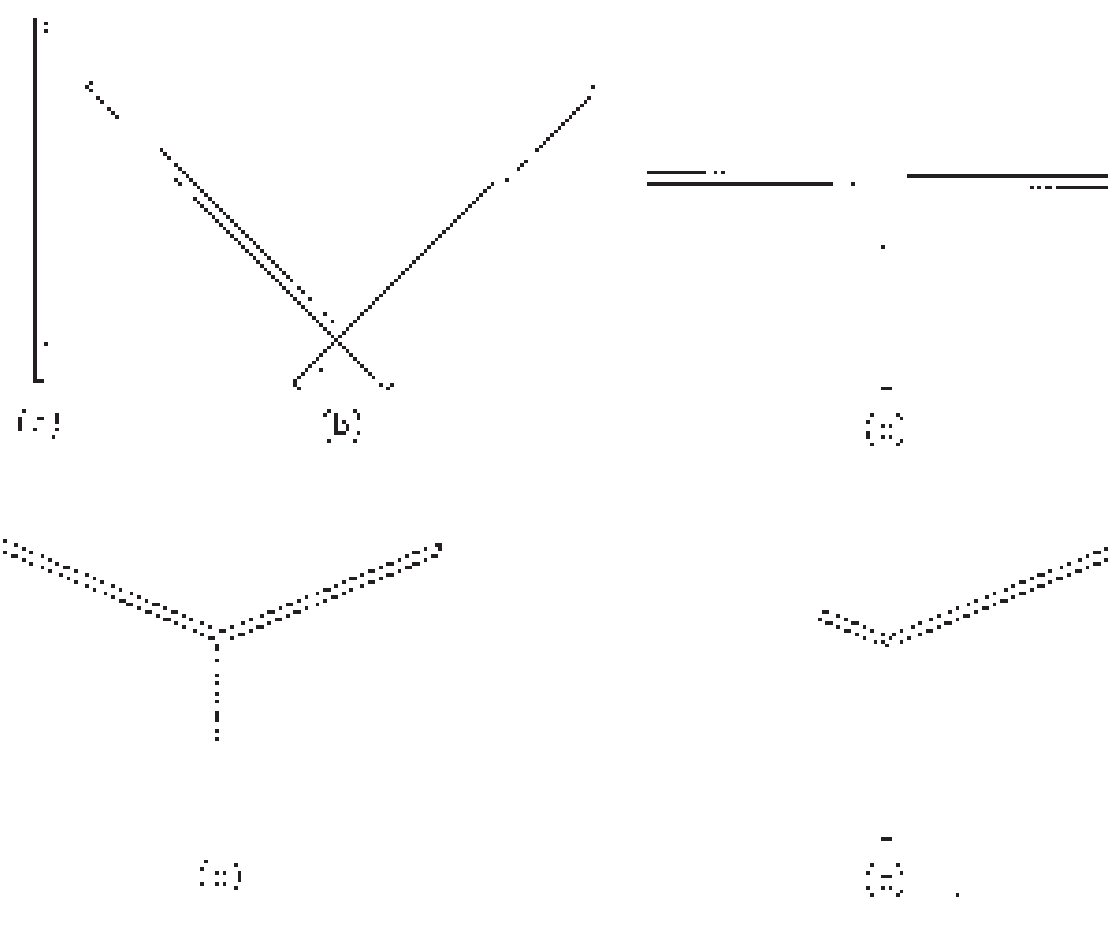

Fig. 1. Experimental blackberry trellis systems: (a) I, (b) V, (c) $T$, (d) $Y$, and (e) rotatable cross-arm Y. 
Fig. 2. Schematic of rotatable cross-arm Y trellis. systemsevaluated, supportswere constructed with standard 1.5-inch (38-mm) welded black pipes for better stability. Galvanized hightensile wire (12.5 gauge) was used in all the trellis systems. Other points considered in these trellis designs were the cost of materials and fabrication, cropping efficiency, and whether they would be compatible with cultural methods used and could be harvested mechanically. In the last ten years, modified trellis support designs such as $T, V, Y$, and modified $Y$ with a rotatable cross-arm (RCA) have been investigated (Figs. 1 and 2). The details of fabrication and installation techniques for these trellis systems are discussed by Peterson et al. (1992) and Takeda and Peterson (1996).

\section{Cane training and pruning techniques}

All the trellis systems, except the I trellis, allowed the floricanes and primocanes to be separated into two canopies. To do this, canes needed to be trained weekly throughout the summer oncethey werehigh and strong enough to be pulled or bent. In the $V$ trellis, primocanes were tied to the bottom wire on the side of trellis not occupied by floricanes. U p to five primocanes per hill were trained on the wire. When they grew 8 inches $(20 \mathrm{~cm})$ beyond the top wire, they were pruned back to the top wire. In late summer, the hanging lateral canes were mechanically hedged to prevent them from tip layering. Small primocanes that emerged later in the season were usually removed at ground level. I n the winter, selected lateral canes, oriented along the row, were shortened to 15 nodes and tied to trellis wire. All other lateral canes were removed.

In the $T$ and $Y$ trellises, primocanes were trained up to a wire at the top of post. The primocane tips were then bent so that the subsequent growth would be horizontal ei- ther along the wire or perpendicular to it. O n plants where the primocanes were bent parallel to the wire, the canes were tipped when they reached the next plant. The lateral canes that developed on the horizontal portion of the primocanes were pulled down and tied to wires on the cross arm not occupied by floricanes. Lateral canes that could not be tied to the trellis were removed. O n plants where the primocanes were trained to grow perpendicular to the row and to the side not occupied byfloricanes, theshootsweretipped as they grew beyond the outermost wire to promote lateral cane growth. After harvest these lateral canes were pruned back to $\approx 15$ nodes and tied to wire on the cross arm.

The permanent, wide cross-arms of the $T$ and $Y$ trellises made many primocanes inaccessible. So to make them more accessible, the RCA Y trellis system was developed. In the RCA Y system, primocanes $>40$ inches $(1 \mathrm{~m})$ tall were tied to the training wire on the center post and bent to grow horizontally to the next plant where they were tipped. The lateral shoots on the horizontal portion of primocanes grew mostly upward and were confined between the main trellis cross arm and short stationary arm (Fig. 3a). L ateral canes that grew downward and could not be repositioned over the wires were pruned.

In the fall, the main trellis cross-arm was swung over to the side with the short stationary arm (Fig. 3b). The lateral canes were then tied to the top or outermost wire on the main trellis cross arm and trimmed back. During this period, ties that held the lateral portion of primocanes to the training wire were removed. The cross-arm was left in thisposition or $\approx 22.5$ degrees above the horizontal. In late spring when most of the primary flowers had opened (Fig. 3c), the cross-arm was again swung back to the other side for harvest operation (Fig. $3 d)$. When most of the secondary flowers had bloomed, a crew of three workers rotated the entire row of trellis cross-arms with the lateral canes attached to the outer wire by rotating each cross-arm 135 degrees about the pivot point at the top of post to the other side of the post. Therotation of trelliscrossarms resulted in the fruiting laterals that were previously upright to hang from the lateral canes. Therotation of crossarms occurred without any loss of floricanesor fruiting laterals. The leaves on the fruiting laterals reoriented themselves within 2 weeks. After harvest the floricanes were removed from the main cross-arm.

The angle at which the 


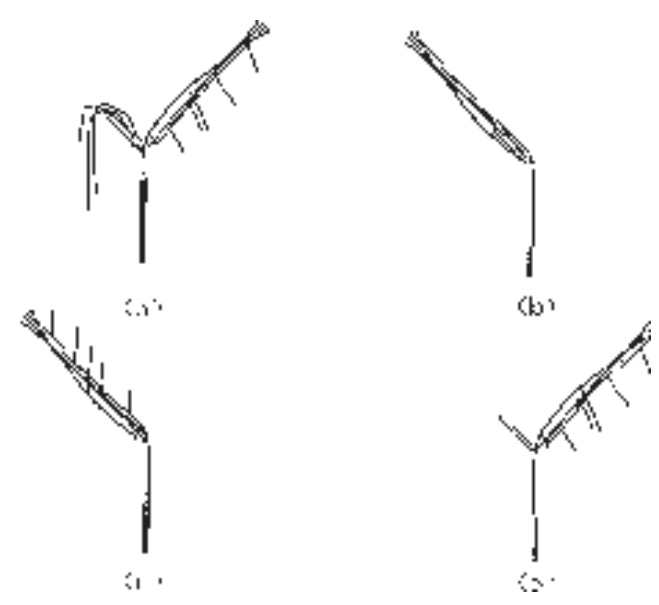

Fig. 3. R otatable cross-arm $Y$ trellis (a) in $J$ uly with the rotatable cross-arm for machine harvest and the short, stationary arm catching lateral canes, (b) after harvest, with the cross-arm rotated for lateral cane tying, (c) at peak bloom in early June, showing the orientation of flower clusters, and (d) postbloom with the cross-arm now pivoted to the other side of trellis post for harvest. N ote that now the fruiting laterals are positioned below the canopy.

cross-arm was positioned during the period from budbreak to full bloom affected the distribution of flowering shoots on the trellis. The relationship between the orientation of lateral canes achieved with the cross-arm of $Y$ trellis system set at different angles and the amount of flowering shoots that developed above the cross-arms is shown in Fig. 4. In summary, the resultsindicated that the closer the trellis cross-arm was held parallel to the ground the greater the proportion of flowering shoots that emerged above the cross arm. $O$ rientation of lateral canes to $<30$ degrees above the horizontal during the period following budbreak until an onset of bloom maximized the numbers of fruiting laterals developing above the trellis cross-arms (Fig $3 c)$. The rotation of the cross-arms to the harvest position placed these fruiting laterals now under the canopy (Fig. 3d). The distribution of flowering shoots in a vertically oriented trelliswas $\approx 55 \%$ and $45 \%$ with greater numbers of flowering shoots emerging to the east side of a north-south oriented row (Fig. 4).

\section{Advantages and disadvantages of trellis systems}

The $V$ trellis provided a narrow, unobstructed hedge-likestructure and separation of floricanes and primocanes. The angle between the two posts was set sufficiently wide to allow the shaking heads of the U SD A experimental brambleharvester insidethe $V$ to shakethefruit from the top and detach fruit onto a catching surface located to the outside and below the fruiting canopy. The $V$ trellis had a span between thetwo postsat their apex of $\approx 10 \mathrm{ft}(3 \mathrm{~m})$ and required a row spacing of at least $22 \mathrm{ft}(6.5$ $\mathrm{m})$, which makes it impractical for commercial blackberry operation.

In the $T$ and $Y$ trellis systems, the shaking mechanism could be positioned above the fruiting canopy and the fruit-catching surface just below the canopy. The distance the fruit fell was rather short, thus minimizing fruit damage. H owever, there were some disadvantages to these two trellises. F ruiting laterals developed upward above the tied canes and fruit were exposed to the sun, resulting in higher incidences of sun scorched fruit. Field observations indicated that insects, such as the J apanese beetle, preferred feeding on fruit on the upper canopy surface than in the canopy interior or lower canopy surface (unpublished data). Also, direct contacts on the fruiting laterals by the shaking rods caused more breakage of fruit clusters and severely bruised some fruit.

The RCA trellis system simplified the primocane training procedure and reduced labor required for summer cane training (H arper et al., 1998). In this system, which permitted the reorientation of theestablished canopy, thefruiting lateralscould be oriented downward below the trellis cross-arm. The fruit was thus shaded by the foliage and exposure to direct sunlight was decreased. During machine harvest, the shaking rods mainly vibrated the lattice of lateral canes on the trellis wires and direct impact of the fruit was minimized. The harvester's catching surface could be positioned directly underneath the fruit clusters, minimizing the distance the detached fruit fell. Another advantage of this system is that rows could be established using the conventional, commercial row spacing of
Fig. 4. R elationship between the angle of cross-arm for training lateral canes and percentage of flowering shoots devel oping upward above the tied canes.

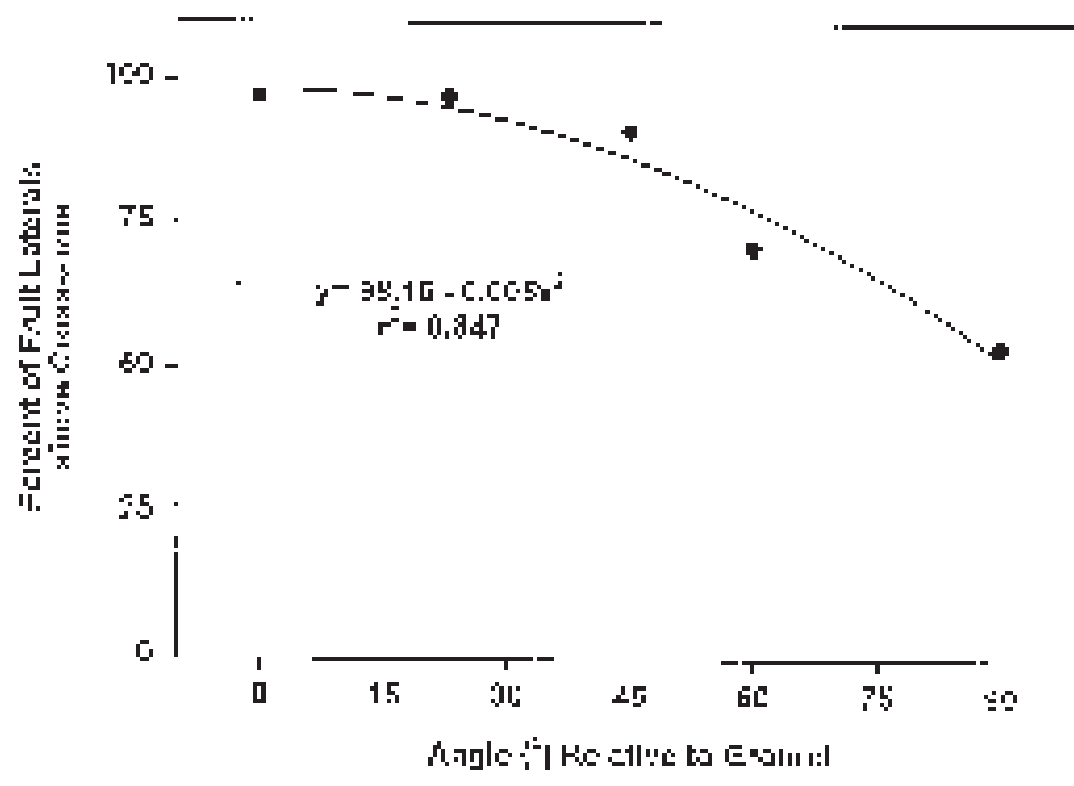




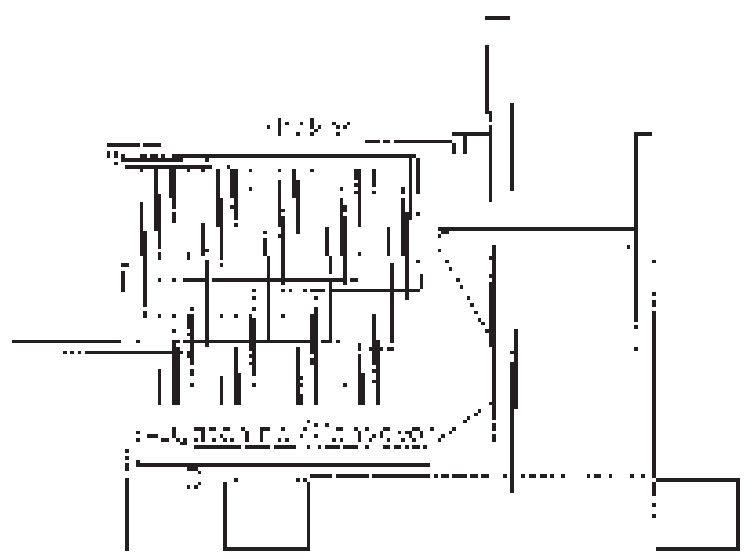

$\therefore$ :

Fig. 5. Schematic of trailer-mounted U SD A blackberry harvester showing (a) front view and (b) side view.

$11 \mathrm{ft}(3.3 \mathrm{~m})$. It also hastheflexibility of permitting an efficient hand harvest of fruit when the cross-arm ispositioned at 60 degreesfrom the horizontal. I n contrast, other trellis systems evaluated for split canopy development and machine harvestabilityrequired much wider, commercially unacceptable row spacings. The major disadvantage of this system was the significantly higher cost of fabricating the rotatable cross-arm system.

\section{Machine harvesting developments}

Traditional mechanical blackberry harvesters use three types of shaking mechanisms. The first consists of one or more pairs of oscillating horizontal beater bars that provide a slapping action to remove the fruit (Booster et al., 1983). The second uses a spiked drum that is oscillating in horizontal plane relative to the rotation of the drum, activated by either an inertia drive (Weygandt, Inc., Canby, O re.) or an eccentric cam mechanism (Blueberry Equipment, Inc., South $\mathrm{H}$ aven, $M$ ich.). The third uses a spiked drum that is oscillated vertically (Korvan, Inc., Lynden, Wash., and Littau, Inc., Stayton, O re.).

In 1988, we began blackberry harvest mechanization research. A prototypeharvester with positive-displacement spikedrumsimparted nearly uniform displacement and acceleration within thefruiting canopy (Peterson et al., 1989, 1992). It wasrelativelysimple in design and initially all harvesting components were mounted on a twowheeled trailer that could be towed by a tractor (Fig. 5).

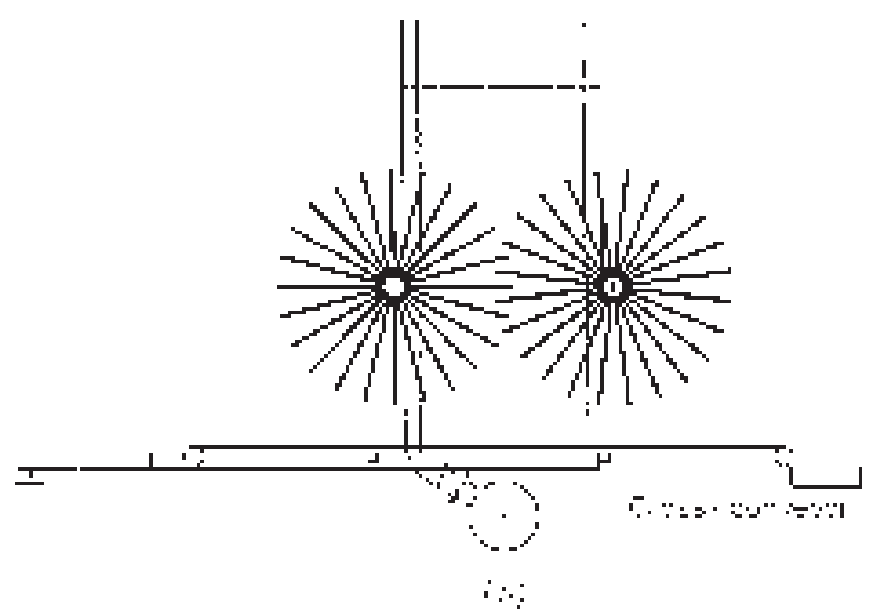

This trailer-mounted prototype harvester was used to harvest ' Chester Thornless', 'Hull Thornless', and 'Thornfree' blackberries trained to $T$, $V$, and $Y$ trellis systems every $2 d$ throughout the harvest season in 1990, 1991, and 1992 (Peterson et al., 1992). Very few fruit fell to the ground because, in these trellis systems, the fruiting laterals were located away from the plant crown. Fruit removal from $\mathrm{V}$ trellis was acceptable. M ore than $90 \%$ of ripe fruit was detached while limiting the detachment of immature fruit to $<10 \%$ of the total harvested. In the $\mathrm{T}$ and $\mathrm{Y}$ trellises the harvester removed $85 \%$ and $88 \%$ of the ripe fruit, respectively.

$\mathrm{H}$ arvested fruit was acceptable for processing, with total soluble solids of $9.1 \%$, titratable acids of $0.8 \%$, and $\mathrm{apH}$ of 3.5 ( $\mathrm{H}$ alat et al., 1997). Alternateday harvest schedules minimized the amount of overripe fruit. These early field tests indicated that 'C hester Thornless' fruit were firm enough to be harvested mechanically and retain theirfresh-market quality. ' $\mathrm{H}$ ull Thornless' and 'Thornfree' fruit were too soft. Fruit on canes hanging below the trellis or on long fruiting laterals could not be shaken vigorously enough to be detached. Fruit from the $T$ and $Y$ trellises had better quality as they had shorter distances to fall to the catching surface than those from the $\mathrm{V}$ trellis.

In 1995, 'Chester Thornless' blackberries trained to $\mathrm{T}$ and $\mathrm{Y}$ trellises were machine harvested on alternate days. The harvesting machine had a cushioned, horizontal conveyor installed to catch the fruit. The conveyor carried fruit to the rear of the harvester where it was transferred laterally by another conveyor belt into containers. $\mathrm{H}$ and sorting of fresh-market-quality fruit was done on the cross conveyor belt. As much as $70 \%$ of the machine detached fruit was fresh-market quality. Q uality evaluations of fresh-market-quality fruit stored for $7 \mathrm{~d}$ at $45^{\circ} \mathrm{F}$ $\left(7^{\circ} \mathrm{C}\right)$ indicated that the fruitswere free of molds and still relatively firm. Juice did not leak from the fruit. The results suggested that the U SD A experimental blackberry harvester can effectively machine harvest thornless blackberry cultivars such as 'Chester Thornless' with fresh-market quality.

In 1997, a new harvester, designed specifically to machine harvest blackberries on the RCA trellis system, was field tested (Fig. 6). Theinsidetunnel of the harvester was $9 \mathrm{ft}$ wide $\times 10 \mathrm{ft}$ high ( $2.7 \mathrm{~m}$ wide $\times 3.0 \mathrm{~m}$ high) and the overall width of the machine was $13.7 \mathrm{ft}$ (4.1 m). A single spiked-drum shaker was installed inside the tunnel. The $4 \mathrm{ft}$ $\times 8$-ft $(1.2 \times 2.4-\mathrm{m})$ cushioned and moving catching surface was located under the shaker unit and inclined 18 degrees from the horizontal. The moving catching surface conveyed the fruit to a transfer conveyor on one side of the harvester where leaves and trash were separated and immature, bruised, and overripe fruit were hand sorted. Freshmarket-quality fruit dropped into halfpint $(0.25-\mathrm{L})$ plastic tills.

'C hester Thornless' blackberries on the RCA trellis system were machine harvested every other day throughout the harvest season with the prototype over-the-row harvester. The harvester was operated at 5 to 6 $\mathrm{Hz}$ with maximum displacement at the tips of the rods set at 7 inches ( 175 $\mathrm{mm})$ and at a $0.6-\mathrm{mph}\left(1 \mathrm{~km} \cdot \mathrm{h}^{-1}\right)$ ground speed. The spike-drum shaker was lowered to a height above the canopy to achieve maximum insertion of nylon rods into the fruiting canopy. A crew of five sorted and packed the fruit. The shaking unit easily moved through theslanted fruit canopy. $\mathrm{H}$ ow- 
Fig. 6. Schematic of U SDA fresh blackberry harvester.

ever, some breakage of fruiting laterals and excessive removal of immature fruit occurred during the initial two harvests. Between $40 \%$ and $70 \%$ of the machine-harvested fruit was in the fresh-market category and the rest was in the overripe, bruised, leaky, or immaturecategories. An economic evaluation of machine harvesting blackberries for fresh market indicted that the rotatable cross arm trellis system would need a packout of $71 \%$ to equal the fresh market return of aconventional I trellissystem that is hand harvested ( $\mathrm{H}$ arper et al., 1998).

\section{Conclusions}

The ultimate goal of machine harvesting eastern thornless blackberries with a high percentage of fruit with fresh-market quality now appears attainable. Wenow havedeveloped ablackberry harvester that can remove $90 \%$ of the ripe fruit without removing immature fruit. N ew trellis designs and canetraining procedures have contributed to high machineharvestability of semierect blackberry. These improvements in the management of blackberry plants have increased the quality of machine harvested fruit and reduced the work needed to train and tie primocanes without sacrificing blackberry productivity.

A new over-the-row, singlespiked-drum shaker, which can effectively detach ripe fruit from a horizontally oriented canopy, was developed. I ts size and maneuverability are similar to conventional shakers designed for harvesting vertically oriented canopies. I ts moving fruit-catching surface positioned just underneath thefruiting clusters will reduce fruit bruising and damage. In the next several years, additional field work will be done to evaluate different shaker oscillating frequencies and stroking span to improve fruit removal and quality. After the harvester has been developed further and canopymanagement strategiesrefined, the best way to mechanically harvest blackberries will be determined.

\section{Literature cited}

Booster, D.E. 1983. Berry harvesting: I I I. C ane and high bush berry harvesting, p. 519-523. In: M. O'Brien, B.F. Cargill, and R.B. Fridley (eds.). Principles and practices for harvesting and handling fruits and nuts. AVI Publishing Co., Westport, Conn.

Brown, G.K., D.E. M arshall, B.R. T ennes, D.E. Booster, P. Chen, R.E. Garrett, M. O'Brien, H.E. Studer, R.A. Kepner, S.L. H edden, E.E. Hood, D.H. Lenker, W.F. M illier, G.E. Rehkugler, D.L. Peterson, and L.N . Shaw. 1983. Status of harvest mechanization of horticultural crops. Amer. Soc. Agr. Eng. (St. J oseph, M ich.) Paper 83-3.

D unn, J.S, M. Stolp, and G.G. Lindsay. 1976. $M$ echanical raspberry harvesting and the Lincoln canopy system. Amer. Soc. Agr. Eng. (St. J oseph, M ich.) Paper 76-1543.

H alat, M.S., C.A. Reitmeier, F. Takeda, and D.L. Peterson. 1997. Sensory evaluation of jams made from three eastern thornless and M arion blackberries. J. Food Q ual. 20:177188.

H arper, J.K., F. Takeda, and D.L. Peterson. 1998. Economic evaluation of improved mechanical harvesting systems for eastern thornless blackberries. D ept. Agr. Econ. Rural Sociol., Pa. State U niv., U niversity Park, Staff Paper 321.

Kingston, C.M. 1991. Defining fruit losses in machine-harvested raspberries. N.Z. J. Crop H ort. Sci. 19:275-281.

M artin, L.W. and F.J. Lawrence. 1976. A synopsis of mechanical harvesting of Rubus in O regon. Acta H ort. 60:95-98.

Moore, J.N. and R.M. Skirvin. 1990. Blackberrymanagement, p. 214-244. In: G.J . G alletta and D.G. H imelrick (eds.). Small fruit crop management. Prentice H all, Englewood Cliffs, N.J.

Morris, J.R., G.S. N elson, A.A. Kattan, and D.L. Cawthon. 1978. D eveloping a mechanical harvesting and production system for erect blackberries. H ortScience 13:228-235.

O ydvin, J. 1986. The Gjerde method for training raspberries. Effects of increasing cane number and cane height. Acta H ort. 183:173-181.

Peterson, D.L., F. Takeda, and T. Kornecki. 1989. N ew shaking conceptsfor brambles. Trans. Amer. Soc. Agr. Eng. 32:1165-1168.

Peterson, D.L., F. Takeda, and T. Kornecki. 1992. $\mathrm{H}$ arvester for " $\mathrm{T}$ ", " $\mathrm{V}$ ", and " $Y$ " trellised eastern thornless blackberries. Appl. Eng. Agr. 8:9-12.

Steiner, P.W., C.S. Walsh, and E.R. Krestensen. 1983. M aryland commercial small fruit recommendations. M d. Coop. Ext. Bul. 242.

Stiles, H .D . 1995. Shift-trellises for better management of brambles (R ubus cvs.). Va. Agr. Expt. Sta. (Blacksburg) Bul. Ser. 95-2.

Takeda, F. and D.L. Peterson. 1996. M echanical harvester, trellis designsand canetraining for eastern thornless blackberry production. Proc. 1996 Annu. Conf. N. Amer. Bramble Growers Assn., Cumberland, M d.

Takeda, F., D .L. Peterson, J.D. Franklin, and T. Kornecki. 1989. M achine harvesting system for eastern thornless blackberries. Acta Hort. 262:411-419.

Warmund, M.R., F. Takeda, and G.A. Davis. 1992. Supercooling and extracellular ice formation in differentiating buds of eastern thornless blackberry. J. Amer. Soc. H ort. Sci. 117:941945. 


\section{Developing Mechanized Systems for Producing, Harvesting, and Handling Brambles, Strawberries, and Grapes}

Justin R. M orris

AdDitional IndeX words. abscission layer, fruit maturity, mechanization systems, mechanical harvesting, mechanical shoot positioning, mechanical pruning, processing

Summary. M echanization of harvesting, pruning, and other cultural operations on many small fruit crops for the processing market has occurred in response to the scarcity and expense of hand labor. Scientists at the Arkansas Agricultural Experiment Station and other experiment stations in the $U$ nited States and throughout the world have developed new cultural and fruithandling systems and have determined the effects of these systems on fruit yield and quality. This research has resulted in the development of prototype and commercial machinery as well as production and handling systems that have assisted in mechanization systems for brambles, strawberries (Fragaria xananasa D uch.), and grapes (Vitissp.). M uch of this body of work is in commercial use and much is simply available, awaiting circumstances that will be beneficial to implementation.

$\mathrm{F}$

or some crops, harvest labor accounts for as much as two-thirds of the total labor costs. Fruit producers generally use hand labor as long as it is available at a reasonable cost, since mechanization requires large capital investments and often reduces the producer's flexibility to change from one crop to another. Consequently, the technology for mechanization has usually been developed long before implementation.

$M$ igrant workers have provided much of the harvest labor. U ntil recently, there was little concern for the welfare of these workers by either the employer or the government. E ventually, concern about the problems of the migrant workers resulted in major changes and improvements in wages, housing, education, and health benefits. These developments increased the cost of harvesting and have led to an increased interest in harvest mechanization so that producers can remain competitive and maintain an inexpensive supply of fruit for consumers. This interest in mechanization has brought about developments for producing and harvesting brambles, strawberries, and grapes.

\section{Brambles}

H ARVESTERS. Successful mechanical harvesting systems have been developed for many fruit, with brambles and grapes being outstanding examples. 
The bramble harvester has, with minor adaptations, been used to pick erect and trellised blackberries (R ubus subg. rubus), black raspberries ( $R$ ubusoccidentalisL.), red raspberries ( $R$ ubusidaeusL.), and gooseberries ( $R$ ibes hirtellum $M$ ichx.). By the mid1960 s, there were $\approx 30$ commercial machines operating in raspberry plantations in the U nited States (D ale et al., 1995). The prototype developed in 1964 at the U niversity of A rkansas was one of the first harvesters developed and operated by mechanical shaking of the canes (M orris et al., 1978b). The cane fruit develops an abscission layer at maturation, which allowsthe moremature fruit to be harvested when shaken. All modern self-propelled commercial pickers work on this shaking principle using sets of horizontal beaters positioned in a vertical plane on each side of the row (Fig. 1). These improved beater arms on the modern commercial harvesters allow for a reduction in the number of strokes needed per minute to harvest the fruit, and cause the least amount of damage to the new canes compared to the original prototype.

The range of 100 to 150 strokes per minute at a ground speed of $1 \mathrm{mph}$ (1.6 $\mathrm{km} \cdot \mathrm{h}^{-1}$ ) is adequate to harvest only the ripe fruit. This frequency of stroke also provides a complete shaking throughout the hedgerow. This is important, since berries that are allowed to remain in the interior of the hedgerow often develop mold and contaminate the next harvest. Most self-propelled commercial bramble harvesters should have the feature of being able to beraised, lowered and leveled to fit the plane of the field and the height of the canes. The need for this capability is due to the low fruiting habit of many of the cane fruit crops. The Arkansas harvester collects all fruit above 15.5 inches $(40 \mathrm{~cm})$ and is only one of several successful cane fruit harvesters currently in use. The commercial model of the Arkansas harvester, with one operator and four field graders, can do the work of 80 to 85 handpickers.

Fruit Quality. U nlike hand harvesting, machines are able to o perate at night to allow for the harvesting of fruit at a lower temperature (M orris et al., 1978b). Research and experience have shown that night harvesting is necessary in warm production regions to maximizefruit quality. Themechanically harvested fruit can be of better quality than hand-harvested fruit when all operations are carried out in a proper and timely manner. $M$ achine-harvested berriesarelarger and have higher total soluble solids, lower acidity, and superior color compared to hand-harvested berries, which generally do not have uniform maturity (M orris et al., 1978b). By machine harvesting at the lowest possible temperature, fruit quality can be maintained during subsequent handling before processing.

Treating brambleswith thegrowth regulator ethephon before harvest can improve the fruit quality. Ethephon reduces the number of required harvests, increases color, and lowers acidity of both raw and processed blackberries (M orris et al., 1978a; Sims and Morris, 1982). Most insects can be eliminated from canefruit before machine harvesting by following recommended spray programs for specific insect problems. Of those that remain, $95 \%$ can be removed before processing by a washing technique in which infested berries pass through water containing adilutenonal kaline, anionic wetting agent. There is no loss of quality with this method (Crandall et al., 1966; Christensen et al., 1973).

Cultural systems. I n many cases, modifications of old cultural systemsmust be made to successfully machine harvest brambles. A mechanical pruner, developed at the U niversity of Arkansas, properly shapes the hedgerow for maximum harvesting efficiency of erect cane fruit (Morris et al., 1978b) and reduces the labor necessary for pruning. 0 ld canes left in the hedgerow, do not affect yield or fruit quality.

$\mathrm{H}$ edgerow culture of erect blackberries is conducive to mechanical harvesting. Five to seven harvests at 4- to 5-d intervals may be required to harvest the entire crop mechanically; therefore, it is desirable to breed for concentrated maturity to reduce the number of harvests. B reeding programs on brambles

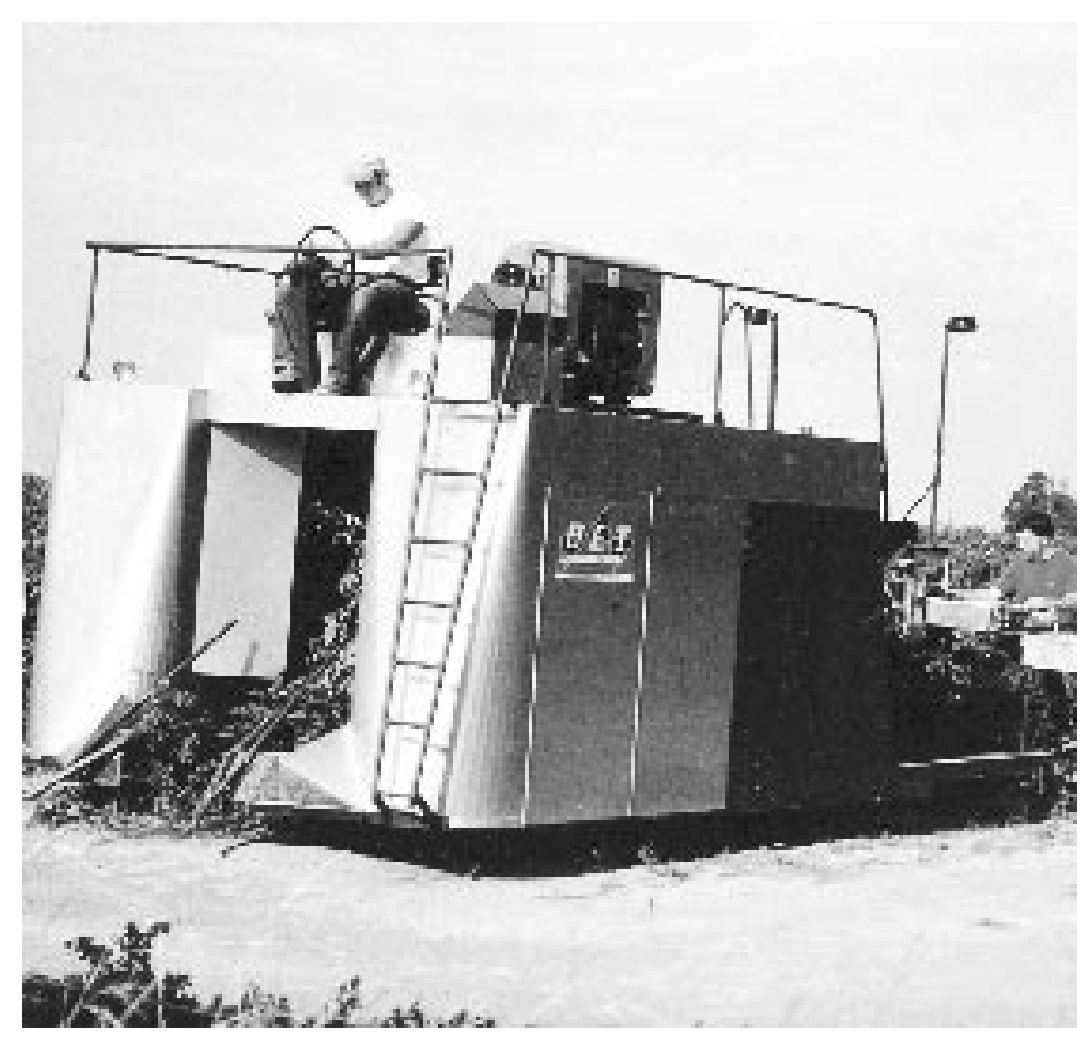

Fig. 1. Commercial model of U niversity of Arkansas cane fruit harvester, manufactured and sold by B lueberry Equipment $\mathrm{C}$ o., Inc., South $H$ aven, Mich. 
Fig. 2. First commercial single-row mechanical strawberry harvester developed by the U niversity of Arkansas and manufactured by B lueberry Equipment C o., I nc., South H aven, Mich. A two-row harvester was successfully tested and used commercially in Oregon. at someland-grant institutions, at the U SD A, and in Canada have developed cultivars of erect blackberriesthat adapt well to mechanization (M oore, 1979, 1984). Thesebreeding programs remain active and should continue to produce more cultivars better adapted to mechanical harvesting.

Most blackberry plantings need to be renovated after 5 or 6 years. R enovation can be accomplished by mowing the entire hedgerow to 3 to 4 inches ( 8 to $10 \mathrm{~cm}$ ) immediately after the final harvest. All mowed canes should be removed from thefield. A mechanical harvester cannot be used in the year following this renovation. However, the fruit from these shorter vines can be hand harvested if an economical supply of labor is available.

The Pacific N orthwest has adapted well to mechanical harvesting of brambles. Growers in 0 regon machine harvest most of their 1500 acres (600 ha) of black raspberries and most of 8000 acres (2800 ha) of trailing blackberries and hybrid berries ( $D$ ale et al., 1995). The lack of rain in harvest season in the Pacific $\mathrm{N}$ orthwest makes mechanical harvesting feasible. Where rainfall at harvest time iscommon, harvest days are reduced, and the softer fruit is more easily damaged, as are the primocanes, which then easily succumb to cane death by the fungus Leptosphaeria coriothyrium (Fckl.) Sacc. (D ale et al., 1995).

\section{Strawberries}

At the U niversity of Arkansas, several harvesting principles had to be evaluated in the process of developing a mechanical harvester for strawberriessince, historically, strawberries have been considered one of the crops least adaptable to mechanization ( $M$ orris et al., 1978c; N elson and Kattan, 1967; N elson et al., 1978).

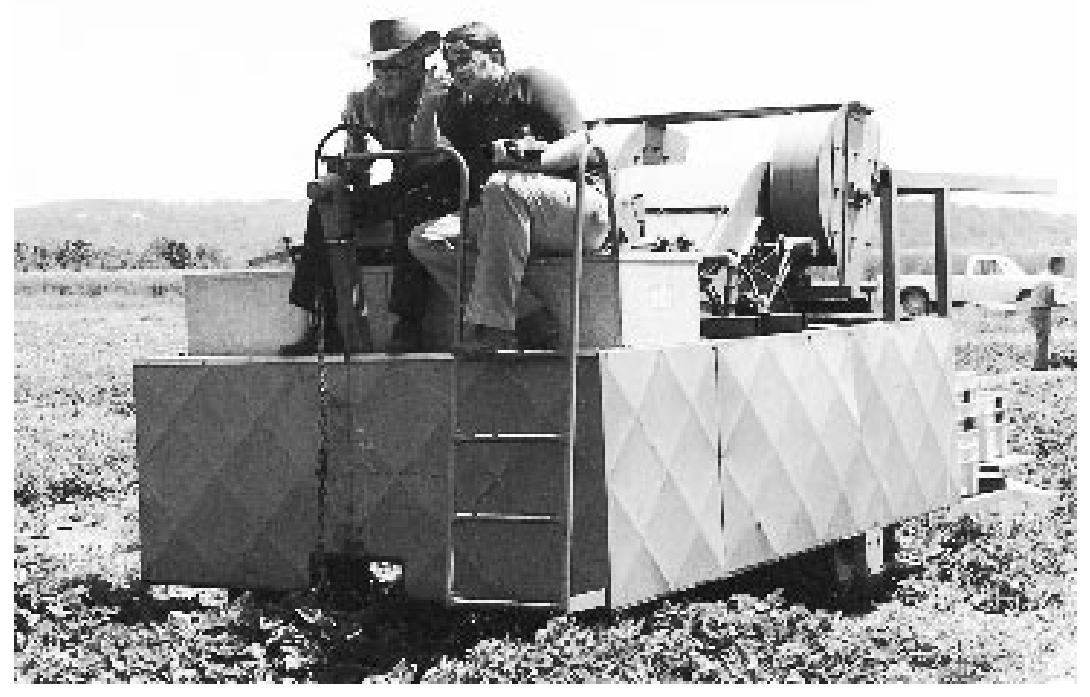

Harvesters. A tractor-drawn prototype of a mechanical strawberry harvester was developed at theU niversity of A rkansasin 1967, and since then it has undergone continual revision (Fig. 2) including development into a self-propelled machine. This prototype was a stripping harvester. It used a reel with alternating brush and comb that raked through the crop. Air suction lifted the berries and foliage (Fig. 3). An airlock berry removal system evacuated the debris while the berries dropped through the airlock valve onto the conveyor. A grower in Copemish, $M$ ich., purchased this machineand suggested that it be built to accommodate two rows for better commercial acceptance. Subsequently, Blueberry Equipment $\mathrm{Co}$., Inc. (BEI), of $M$ ichigan modified and produced the U niversity of Arkansas harvester as a two-row hydraulic-powered machine for commercial sale. In those early years, researchers working with the harvesters mentioned and other types of mechanical strawberry harvesters reported picking efficiencies from 31\% to $87 \%$ (D enisen and Buchele, 1967), 91\% to $97 \%$ (M orris et al., 1978c), and $24 \%$ to $92 \%$ (Booster et al., 1970a, 1970b; Booster, 1973.)

In addition to the $U$ niversity of Arkansas harvester, several others have been developed for strawberries. Three different stripping type machines were developed in I taly during this same period (Di Ciolo and Zoli, 1975; L ucignani, 1979; R osati, 1980), and researchers in D enmark produced a commercial machine called the Danpluck harvester, which uses 62 -inch-wide $(160-\mathrm{cm})$ rakes on a sloping belt to lift the berries. A unique finger reel plucks the leaves from the berries as an air ejector expels them. (Thuesen, 1988).

Q uick and Denison (1970) described a stripping-type harvester that used a bank of diverging, vibrating ramps instead of a reel. Shikaze and Nyborg (1973) developed a variation on this design by replacing the vibrating action with a bank of small belts. $\mathrm{H}$ owever, there has been no commercial use of these machines. M ore recently, $\mathrm{H}$. L ee of the U niversity of Guelph, Canada, and Bragg Enterprises in Canada have developed another version of the stripping harvester (Swinklesand M urray, 1991). Their machine uses a reel with cam-controlled finger bars that work through the plants, stripping the strawberries from their peduncles and dumping them through the cam mechanism onto a conveyor system.

The British $\mathrm{N}$ ational Institute of Agricultural Engineering developed a mowertype harvester that wasmodified by M ichigan State U niversity and then commercialized in somewhat different forms by two machinery companies, Smallford Planters of Silsoe, England, and Conners M achinery, Inc. (CMI), 
of Simcoe, Ontario, $\mathrm{C}$ anada ( $\mathrm{H}$ ansen et al., 1983). The Smallford machineused a cutter bar with fingers that lifted the berries above the bar (Kemp, 1976). The berries were conveyed to a belt where cutting blades clipped the trusses, and debris was blown back into the field. The CMI harvester employed a more effective airblast system to separate the debrisfrom the berriesand used reciprocating clippers to cut berry trusses. The heavy output of this harvester led to the development of mechanisms that would support and allow easy handling of shallow bulk bins and a suitable box-filling system (Lauro

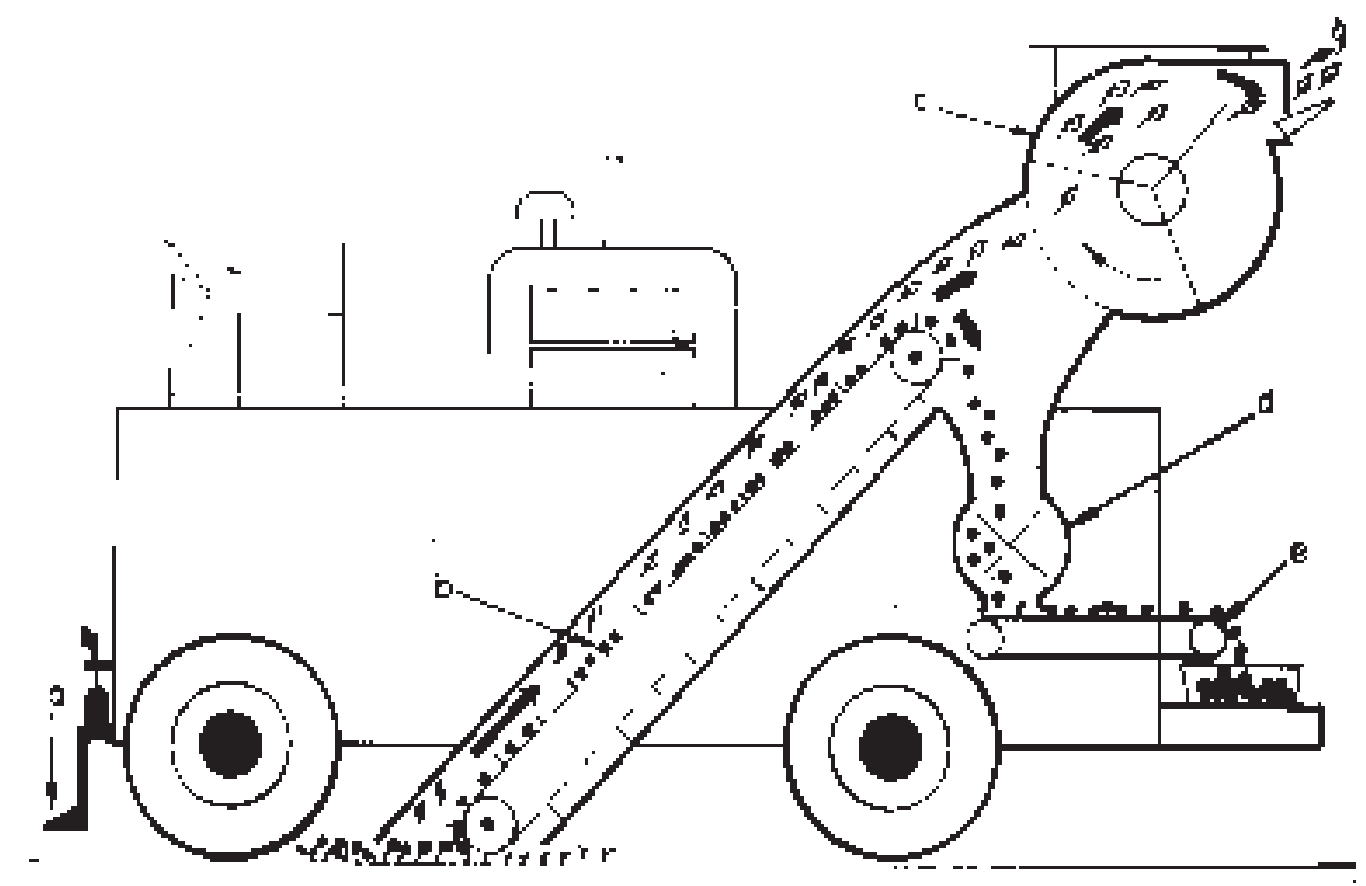

and $\mathrm{H}$ ergert, 1987). R esearchers in Arkansas (Booster, 1973), O regon (H echt, 1980) and Germany (Fiedler, 1987) developed similar harvesters, although the German machine used people seated on the harvester to sort and destem the fruit.

Research at the U niversity of Arkansas has shown that certain strawberry cultivars are more adapted to machine harvesting, cleaning, and sorting without loss of quality (M orriset al., 1978c, 1979c, 1980; N elson et al., 1979). Q uality of machine-harvested fruit from certain strawberry cultivars is improved by prior handpicking (M orris et al., 1979c, 1980). O nce-over machine harvested strawberries, after one or two hand harvests, have had a higher percentage of ripe berries than fruit machine harvested without a previous hand harvest. The percentage of total soluble solids, firmness, and color intensity of the once-over harvested strawberries after one or two hand pickings was the same or higher than that of hand-harvested fruit ( $M$ orris et al., 1980). Senso ry quality of fruit puree from both machine-harvested and hand picked fruit was rated as acceptable.

O ne of the most objectionableaspects of machine-harvested strawberries is the presence of green, immature fruit. $M$ any immature berries can be separated from mature fruit in the processing plant, based on fruit size. $\mathrm{H}$ owever, large green fruit that is sorted with the large ripe fruit eventually ends up in the processed product. Research has shown that strawberry products made from cultivars containing high anthocyanin levels can tolerate as much as $50 \%$ immature fruit in the production of commercially acceptable jam (M orris et al., 1979a; Sistrunk and M orris,
1978). Strawberry jam made from 'C ardinal' strawberries, which have extremely high anthocyanin levels, can contain as much as $75 \%$ large immature fruit and still be rated acceptable (Spayd and M orris, 1981).

Strawberries are highly perishable. Research has shown that extremely firm-fruited strawberries for processing can be mechanically harvested, properly cleaned and handled, and then held for up to $48 \mathrm{~h}$ at $75^{\circ} \mathrm{F}\left(24^{\circ} \mathrm{C}\right)$ and up to $7 \mathrm{~d}$ at $35^{\circ} \mathrm{F}\left(1.7^{\circ} \mathrm{C}\right)$ without excessive quality loss ( $M$ orris and Cawthon, 1979). It also showed that fungicide dips before storage suppress mold growth and reduce loss of soluble solids. An acetaldehyde atmosphereand a combination of atmospheres and dips are effective in maintaining good color, freedom from browning and product acceptability of machine-harvested strawberries held for $72 \mathrm{~h}$ at $75^{\circ} \mathrm{F}\left(24^{\circ} \mathrm{C}\right.$ ) (M orriset al., 1979a, 1979c). H owever, these techniques havenot been commerciallyimplemented since it has never been practical to use machineharvested fruit for thefresh market, and berries are usually processed immediately.

Currently, only onestrawberry harvester is operating commercially in O regon. This harvester was developed by the $U$ niversity of Arkansas and manufactured by BEI (Figs. 2 and 3 ). The machine is used to strip the mature fruit remaining after one or two hand harvests. This fruit is being processed in a puree product. I mprovement in strawberry cultivars that would make them better suited for once-over harvest or better suited for multipleharvest, or improvementsin harvesting machines will be required before large scale mechanization of strawberries will be used.
Fig. 3. U niversity of Arkansas mechanical strawberry harvester: (a) mowing sickle bar, (b) comb-brush picking and conveying system, (c) fan, (d) airlock valve, and (e) fruit transporting conveyor. 


\section{Grapes}

$M$ ajor developments in juice and wine grape harvest mechanization occurred in the early and mid-1960s (O Imo, 1980; Shepardson and M iller, 1962; Shepardson et al., 1969; Studer and O Imo, 1969), and mechanization was practiced commercially by the late 1960s (J ohnson, 1977; M arshall et al., 1972). M echanically harvested grapes can have better quality than handharvested grapes when delivered promptly to the processing unit (Whittenberger et al., 1971). Trellising systems suited for mechanical harvesting and other mechanical operations continue to be a major prerequisite to successful harvesting of grapes.

Harvesters. Basically, there are two configurations of mechanical harvesters, tractor drawn and self propelled. Cattell (1994) reported that the towed models cost between $\$ 40,000$ and $\$ 75,000$. These units can generally be justified when the price of hand harvesting is between $\$ 8,000$ to $\$ 10,000$ ayear. Thesetowed units can easily handle 120 acres (48.6 ha) per season. O ften, the overriding factor in a decision to purchase a harvester is to have total control over when grapes are harvested.

The self-propelled machines straddle the row and cost between $\$ 120,000$ and $\$ 150,000$. They can harvest over 247 acres (100 ha) in the course of aseason. G rapegrowerswith more than 100 acres (40.5 ha) usually consider the self-propelled units. Since these unitshavea larger capacity, some growers do custom harvesting as a side line. In the large grape-producing ar-

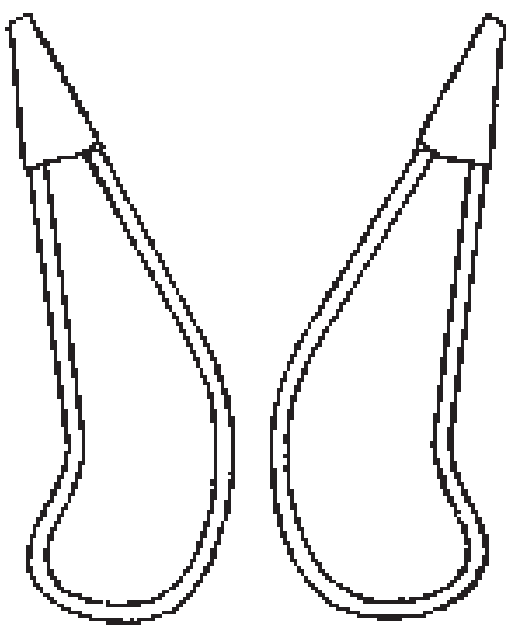

Fig. 4. B ow rods inserted horizontally in the picking field. eas of California, some companies do nothing but custom grape harvesting. These companies use only the overthe-row harvesters. These harvesters can be converted to harvest either a single-wire trellis or a divided doublecurtain trellis, which containstwo separate foliage canopies.

$M$ any of the commercial harvesters use pivotal strikers, arranged as a doublebank of flexiblehorizontal rods, that strike and shake the vine to remove fruit. They can be operated as in phase or out of phase. In phase means both thefront and rear strikersmovein the same direction at the same time. This can cause vibrations, which need to be balanced by counter weights. $\checkmark$ ibrations are not a problem with the out-of-phase pivotal strikers (the type on most older models). H owever, depending on the vine growth, they may not pick as well. Conversion kits are readily available to convert the out-ofphase to an in-phase system.

A nother principleused in California is the trunk shaker in which two parallel rails impart horizontal vibration to the upper trunk and/ or cordon. Thetrunk shaker is most effective in removing fruit located close to a rigid trunk or cordon, and much less material other than grapes, such as bark, canes, leaves, and petioles, is harvested compared to that with the pivotal striker. Some machines have combined the two principles and reduced the number of horizontal rods.

A nother picking head is the bow head or bow rod unit. Construction may vary from manufacturer to manufacturer, but the shaking elements are round commercial plastic bar stock 1 to 1.5 inches $(2.5$ to $3.8 \mathrm{~cm})$ in diameter and $\approx 5 \mathrm{ft}$ ( $1.5 \mathrm{~m}$ ) long having the general shape of a closed shepherd's staff (Fig. 4). These horizontally oriented bars movetransversely and shake the vine. The shaking action on the leaves is more gentle than with pivotal striker rods, and the longer striking distance results in less defoliation. The bow head also allows for greater harvesting speed. Because of the introduction of the bow head, the trunk shaker is not as popular in California vineyards as it was in the 1980s.

Grape quality. The mechanical harvester makes it possible to harvest at night and the advantages of night harvesting cannot beover emphasized. Grapes harvested at night when temperatures are more favorable for deliv- ery of cooler grapes, result in better quality than grapes harvested in the heat of the day. Research has shown that any type of grape harvested when fruit temperature is high $\left(86^{\circ} \mathrm{F}\right.$ or 30 ${ }^{\circ} \mathrm{C}$ and above) will have poor color and produce high levels of alcohol and acetic acid, both of which are signs of microbial spoilage(M orriset al., 1972). The alcohol and acetic acid levels of mechanically harvested grapes begin to rise after $12 \mathrm{~h}$ from the time of harvest if grape temperature at harvest is as high as $85^{\circ} \mathrm{F}\left(29^{\circ} \mathrm{C}\right)$. D ecreases in solublesolids, flavor, and color quality parallel the increases in alcohol and acetic acid (Benedict et al., 1968; M orris et al., 1979b). O ff-flavors are present in the processed juice product when alcohol levelsreach $0.05 \%$ T hese studies suggest that grapes produced in hot areas, such as the San Joaquin Valley of California and the southern U nited States, should be harvested during cool periods of the day or at night to minimize loss of quality (Benedict et al., 1968, 1973; J ohnson, 1977; M orris et al., 1979b.)

Adding sulfur dioxide $\left(\mathrm{SO}_{2}\right)$ to machine-harvested wine grapes minimizes quality loss during holding (Benedict et al., 1973; Bourne et al., 1963; C hristensen et al. , 1973; M orris et al., 1972, 1979b; O'Brien and Studer, 1977). An applicator is commercially available that will meter a spray solution of $\mathrm{SO}_{2}$ onto the grapes before they enter the bins and is employed principally on wine grapes. Addition of 80 to 160 ppm SO immediately after harvest has been shown to slow postharvest deterioration of machine-harvested juice grapes by reducing browning and delaying alcohol accumulation and loss of solublesolids for $24 \mathrm{~h}$ (M orris et al., 1979b).

Collection and handing. Mechanical harvesters havetwo basic kinds of mechanismsfor collecting thegrapes: a belt system and a bucket system. Grapes that are juiced during harvesting are better handled with the bucket system. H owever, the bow rod picking head harvestsmore intact fruit causing less juicing than the fiberglass rods of the pivotal striker head.

The initial containers used for hauling 'Concords' and other juice grapes to the processing unit were 1 ton $(0.9 \mathrm{t})$ capacity wooden bins with food-grade plastic liners. M any operations have switched to the west coast method, where a 4 to 5 ton (3.6 to 4.5 
t) capacity, hydraulic, self-dumping vineyard gondola is used to transfer harvested wine or juice grapes into open-top, bulk tank trucks.

Guidelines for efficient mechanlCAL haRVESTING. R esearchersat the U niversity of Arkansas in co operation with commercial grape growers have developed guidelines for efficient mechanized harvesting and handling: 1) Select the proper revolutions per min (rpm) of the shaking mechanisms or strikers and the proper ground speed for each cultivar and crop load situation. 2) Establish a time limitation for each cultivar from harvesting to processing plant delivery. 3) 0 ptimize fruit temperature and $\mathrm{SO}_{2}$ usage. 4) Eliminate problems of material other than grapes (MOG). 5) Cease cultivation sufficiently before harvest to minimize dusty conditions. 6) I nspect the vineyard for foliar-feeding insects and, if necessary, apply sprays sufficiently ahead of harvest. 7) Provide a bin or conveyor inspector as part of the harvesting crew to remove M O G, to watch for plugging of cleaning fans, hydraulic leaksand mechanical failures, and to monitor $\mathrm{SO}_{2}$ application. 8) C over harvested grapes at all times and clean the bin after each dumping. 9) Clean mechanical harvestersthoroughly with approved detergent and sanitizer as needed. 10) Install a magnet on the machine's discharge conveyor to collect staples and other iron-containing objects. These guidelines were developed for commercial harvesting of $\mathrm{Vi}$ tislabruscana L . in the eastern U nited States. Similar guidelines have been or should be developed for each region depending on standards established by the processors.

\section{Specialty grapes}

Muscadine Grapes. M uscadines, Vitisrotundifolia M ichx., are used primarily for wine, and most of these muscadine wine grapes are machine harvested. Muscadines are also sold fresh and as juice, jams, and jelly. M uscadine grapes present a challenge for mechanical harvesting since they grow in small clusters that usually contain 6 to 24 large berries. M ature berries of most muscadine cultivars do not adhere to their pedicel as do those of the bunch grapes. This makes muscadines easy to remove, but can cause the problem of fruit dropping in advance of the mechanical harvester. To prevent the loss of this over-mature fruit, an extended collecting unit has been designed that is adaptable to the front of any conventional commercial harvester (Morris, 1994). When using the over-the-row mechanical harvesters that have four sets of beater rods, the front two sets can be removed. This allows the beating action to start after the fruit to be removed has completely entered the harvester.

$M$ achine-harvested muscadines may be sorted effectively according to their density, with the denser berries falling into the riper categories ( $L$ anier and M orris, 1979). D ensity sorting is a rapid and inexpensive method of removing fruit of undesirable maturity. In the 1980 s, when $\mathrm{N}$ orth Carolina had a significant commercial muscadine grapeindustry, onegrower built and successfully used this density separation system. However, today the system isused primarily by scientists to evaluate cultivars and cultural systems for their suitability for once-over harvesting from the standpoint of uniform maturation.

RaIsıns. M echanization of raisin harvest has been more difficult than that for other grapes. A severed-cane or harvest-pruning techniqueto facilitate the mechanical harvesting of ' $T$ hompson Seedless' raisin grapes was reported by Studer and O Imo (1971, 1974). Cutting the fruiting cane near the base and leaving the fruit on the trellis wires for 4 to $8 \mathrm{~d}$ until the pedicels dry allows the grapes to be harvested as single berries by any type of vibrating harvester. The individual berriesare conveyed into ahopper and then metered and spread evenly on a continuous paper strip. The single berries will dry uniformly without being turned. Thedried raisinsare picked up by another machine, with metal fingers that run under the paper strip to guide it to revolving brushes, which sweep the raisins onto conveyors that transport them into bulk bins.

D ried-on-the-vine ( $D O V$ ) raisin production research began in Australia in the late 1950s and early 1960s (M ay and Kerridge, 1967). Parallel efforts were under way in California where the method was used on 'Black Corinth' and 'Thompson Seedless' cultivars. The efforts on DOV Zante currants( from 'Black C orinth' grapes) were successful (Christensen et al., 1970), but the results with 'Thompson Seedless', the primary raisin grape, were disappointing due to their later maturity, higher vigor, and larger berry size (Studer and O Imo, 1973). H arvest-pruned 'Thompson Seedless' grapes dried to $25 \%$ to $35 \%$ moisture after 6 to 9 weeks of vine drying on their standard trellissystems. Attempts to speed up the D O V processincluded oleate sprays (Petrucci et al., 1974), but as in Australia, adequate emulsion spray coverage was difficult to achieve, and the final product was different from the natural 'T hompson Seedless' raisin (Striegler et al., 1996). TheD OV 'Thompson Seedless' raisin sprayed with oleate was not embraced by the consumer. In 1984, the raisin industry enthusiastically embraced the sprayedon-the-tray (SOT) method of raisin production after shallow consumer testing. That year the industry produced 7,745 tons $(7,048 \mathrm{t})$ of SOT raisins, only to have that production fall to 38 tons (34.6 t) in 1988, because consumers did not buy them. Producers were anxious not to repeat this mistake ( $M$ alcolm, 1993).

Although the concept of DOV raisins is an old one, DOV has been given new life through research developments. In the new DOV method, raisins are not sprayed with oil. $\mathrm{N}$ ew trellising systemsand newly introduced seedless grape cultivars have made the spraying step unnecessary. Traditionally, in California, raisins are harvested in September and boxed 12 to $21 \mathrm{~d}$ later, depending on drying conditions. With the present DOV system, canes are cut in August so the chance of rain is very low.

$\mathrm{N}$ ew trellis systems have been developed for DOV production. These trellis systems follow the general principle of separating the vine cano py into fruiting and nonfruiting zones and are designed also to facilitate mechanization of harvest pruning, the cutting of fruiting canes for drying on the vine. Generally, this year's canes are on the south side of an east-west row and next year's canes are in a catching trellis system that provide for maximum sun exposure. The southern exposure gives adequate sunlight exposure and optimum drying conditions. Australia is also actively reviving the D O V system. They have introduced specialized trellising systems along the above described lines: the I rymple system (Gould and Whiting, 1987), the Shaw system (Shaw, 1986), and the swing-arm system (Clingeleffer and M ay, 1981). 
Another manner in which to improve the D OV system is to use specially designed seedless cultivars. Three cultivars are being investigated for use in DOV raisin production. 'Thompson Seedless $2 \mathrm{~A}$ ' isa heat-treated, virus-free clone of 'Thompson Seedless'. It has a proven track record of productivity and is preferred for new plantings of 'T hompson Seedless' for raisins and crushing. 'Fiesta' is a result of a complex cross made in the 1960s at the U SD A H orticultural Field Station in Fresno, C alif. It ripens 10 to $14 \mathrm{~d}$ earlier than 'T hompson Seedless', produces high quality raisins and, after initial concerns over seed traces were laid to rest, has gained supporters in the last several years [3,840 acres $(9,489$ ha) in 1996] (Christensen, 1997). 'D O Vine' is a recent (1995) release by $D$ avid Ramming (USD A) as an early ripening ( 2 to 3 weeks before 'Thompson Seedless') cultivar that is suitable for D OV production (Christensen, 1997). 'D O Vine's' high vigor provides potential for alarge vineframework and a canopy adapted to more expansive trellising and the demands of cane renewal for D O V. I n fact, its greatest potential is with large, expansive D O V trellis systems where the canopy can be spread. Vigor control through controlled drip irrigation and nitrogen fertilization will be necessary in most sites. Vertical or south side systems may not handle the vigor unless these control measures are taken.

All three of these cultivars show appropriate fruitfulness characteristics for D OV. In comparative studies done at the California Kearney Agricultural Research and Extension Center, raisin yields were statistically similar among the cultivars. Berry weights were heaviest with 'Fiesta', followed by 'D O Vine' and 'T hompson Seedless $2 A^{\prime}$. A irstream so rter raisin grades were similar, except the percentage of substandard berries was higher in ' $D O V$ ine' than in 'Thompson Seedless 2A'. R esearchers concluded that 'Thompson Seedless' (the 2A clone) will continue to be a dominant cultivar because of its adaptability, versatility,

Table 1. Effect of thinning double curtain 'Concord' grapes grown at Merritt Vineyard, N.Y, 1997. Source: J oint research by Morris, M ain, and Dunst funded by $\mathrm{N}$ ew York State Agricultural Experiment Station Viticulture C onsortium R esearch G rants Program.

\begin{tabular}{lcccc}
\hline Treatment & $\begin{array}{c}\text { Yield } \\
\text { (tons/ acre) }\end{array}$ & $\begin{array}{c}\text { Soluble } \\
\text { solids } \\
(\%)\end{array}$ & pH & $\begin{array}{c}\text { Red } \\
\text { pigment } \\
(520 \mathrm{~nm})\end{array}$ \\
\hline Control & $13.5 \mathrm{a}^{2}$ & $12.7 \mathrm{c}$ & 3.24 & $4.04 \mathrm{c}$ \\
C-R $250 \mathrm{rpm}$ & $9.9 \mathrm{bc}$ & $14.2 \mathrm{~b}$ & 3.27 & $6.01 \mathrm{~b}$ \\
M-O $200 \mathrm{rpm}$ & $11.5 \mathrm{ab}$ & $13.7 \mathrm{~b}$ & 3.28 & $4.71 \mathrm{bc}$ \\
M-O 225 rpm & $11.0 \mathrm{bc}$ & $14.4 \mathrm{~b}$ & 3.27 & $6.08 \mathrm{~b}$ \\
M-O 250 rpm & $9.2 \mathrm{c}$ & $15.2 \mathrm{a}$ & 3.25 & $8.15 \mathrm{a}$ \\
\hline
\end{tabular}

$\mathrm{z}_{\mathrm{M}}$ eans within the same column having the same letters are not significantly different at $\alpha \leq 0.05$.

${ }^{y}$ Chisholm-Ryder harvester for thinning.

$\mathrm{x}_{\mathrm{M}}$ orris-O ldridge thinning unit. familiarity, and longevity (Christensen, 1997). Industry leaders believe the D OV technique has potential for saving money while improving their operation and producing high-quality raisins. The new D OV systems eliminate pickers, turners, rollers, the traditional boxing crew, and even paper trays. There will be savings in crop insurance as it is presently written and on workers' compensation. Estimates of savings run as high as $\$ 300 /$ acre (2.5 ha) with D OV production (M alcolm, 1993).

In 1992, one prototype harvester for D O V production wasdesigned and manufactured by Ag Right Enterprises of M adera, $C$ alif. The unit is operated by hydraulics and uses a radial-forced balanced shaker unit that gently knocks the raisins off the canes into a catcher with a conveyor belt that takes it up to another conveyor unit that deposits the raisins into a bin trailer running in the adjacent row, parallel to the machine. Another prototype harvester system that is currently being evaluated is manufactured by Korvan I ndustries, Inc., O re.

More time is needed to evaluate the most cost effective trellis systems, handling, and processing. However, industry is concerned about market analysesand the public's acceptance of the characteristics of DOV raisins. In 1993, one raisin board adopted a long-term policy of gradual market development ( $M$ alcolm, 1993).

\section{Other mechanization practices for grapes}

Pruning and thinning. Along with mechanical harvesting, other mechanized processes can improve efficiency in grape production. M echanical pruning can reducehand labor by as much as $50 \%$ Studies in Arkansas on shoot-positioned 'Concord' grapevines trained to Geneva D oubleC urtain (GD C), (a system with two adjacent wires $\approx 4 \mathrm{ft}(123 \mathrm{~cm})$ apart with vines trained on them to form a double curtain of foliage) or bilateral cordon systems (which have one wire with vine cordons running up and down forming a single curtain of foliage) examined the effects of mechanical pruning on yield, vine size, and juice quality. The results showed that continual mechanical pruning of 'C oncord' grapes is recommended only in shoot-positioned vineyards where cane selection and adequate node, shoot or fruit limitation follows pruning. Recent data from the author show that mechanical fruit thinning also eliminates the problem of overcropping without the need for hand thinning. D ata collected in a commercial vineyard in N ew York in 1997 showed that it was possible to mechanically thin a machine-pruned vineyard with the Morris- 


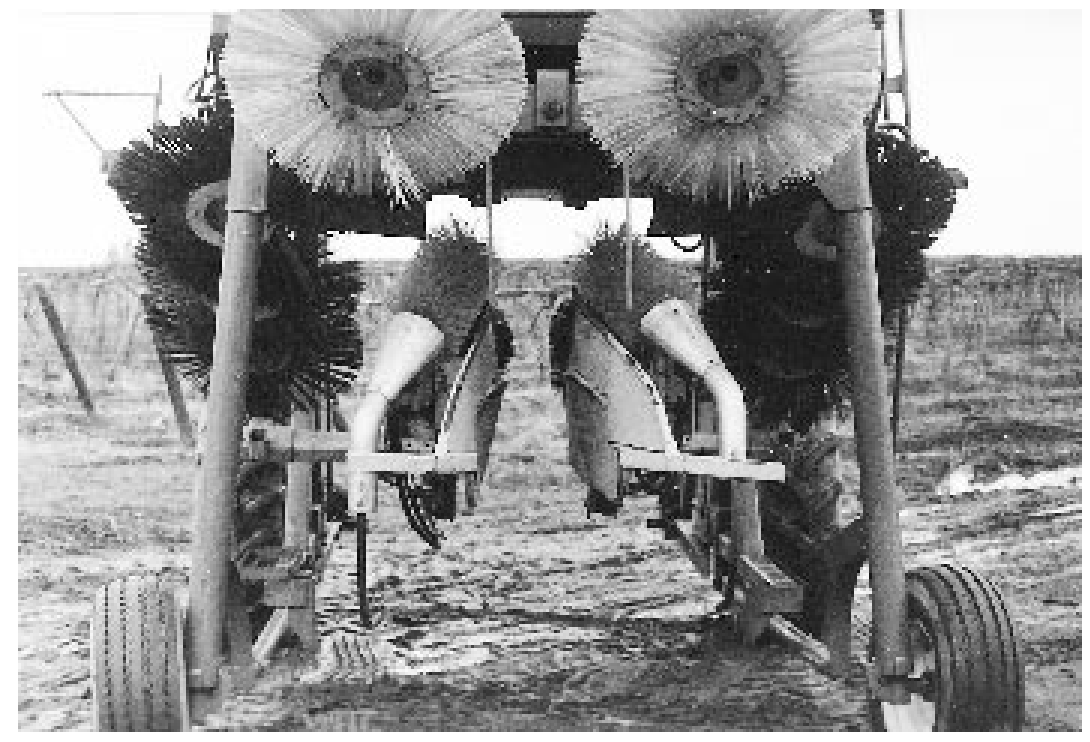

with less damage to fruit and canes.

Completely MECHANIZED SYSTEMS FOR GRAPES. In a cooperative research effort the author and Tom Oldridge, grape grower and inventor from Lowell, Ark, have developed systems for vineyard mechanization, and we have a pending patent on vineyard machinery and systems. TheM orris-Oldridge Sys-

Fig. 5. A G eneva double curtain over-therow mechanical shoot positioner developed by T om Oldridge, L owell, Ark. Adding cutter bars behind converts the machine to a mechanical pruner. These units are used as part of one of the 12 Morris-Oldridge vineyard mechanization systems.

Oldridge thinning unit at $250 \mathrm{rpm}$ and obtain high quality (15.2\%solublesolids) 'C oncord' juice grapes (Table 1 ).

Sноoт positioning. Shoot positioning allowsfor effectivemechanical pruning. Shoot positioning of the canes to avoid shading exposes the lower nodes on the bearing units to sunlight, making these basal nodes more productive, and improving fruit quality (M orris et al., 1984). Positioning is particularly effective on the vigorous V. Iabruscana cultivars. Vines are usually shoot positioned for the first time at first bloom, but complete shoot positioning usually requires a second and possibly a third pass (Fig. 5). A properly shoot-positioned GD C system with two separate foliage canopies is more efficient to harvest mechanically than a nonpositioned canopy. A bilateral or single-curtain system that has been shoot positioned is easier to mechanically prune and mechanically harvest tems provide machines that allow for almost complete mechanization of all vineyard operations. The patent describes a method for complete vineyard mechanization of 12 different trellising systems and methods to modify, trellis, and train grapevines. These developments eliminate expensive hand operations, and production can be economically mechanized without any substantial loss of yield or fruit quality. This patent is the result of studies at the $U$ niversity of Arkansas over the last 32 years that haveinvolved the evaluation of trellising and training systems suitable for complete vineyard mechanization, mechanical shoot positioning, mechanical pruning, mechanical thinning (Tables 1 and 2), mechanical harvesting, and the postharvest handling and use of mechanically harvested grapes (Cawthon and M orris, 1977; M orris, 1985; M orris and Cawthon, 1980a, 1980b, 1981; M orris et al., 1975, 1984).

Currently, two trellising systems can be completely mechanized-the GDC and the single curtain system. In addition, variations of thesesystemscan al so becompletely mechanized. We have designed a complete mechanization system with the apparatus and methods for the mechanization of, not only the juice grapes of Vitislabruscana species, but

Table 2. Effect of thinning and pruning methods on yield and fruit quality of 'C abernet Sauvignon' grapes grown at Vino F arms, I nc., L odi, C alif., 1997.

\begin{tabular}{|c|c|c|c|c|c|c|}
\hline $\begin{array}{l}\text { Pruning } \\
\text { treatment }\end{array}$ & $\begin{array}{l}\text { Thinning } \\
\text { treatment }\end{array}$ & $\begin{array}{c}\text { Yield } \\
\text { (tons/ acre) }\end{array}$ & $\begin{array}{c}\text { Soluble } \\
\text { solids } \\
(\%)\end{array}$ & $\mathrm{pH}$ & $\begin{array}{c}\text { Tartaric } \\
\text { acid } \\
(\%)\end{array}$ & $\begin{array}{c}\text { Anthocyanin } \\
\left(\mathrm{mg} / \mathrm{cm}^{3}\right)\end{array}$ \\
\hline Spur pruned control & None & $11.4 b^{2}$ & $25.2 \mathrm{bcd}$ & 3.78 & $0.54 \mathrm{abc}$ & $0.30 \mathrm{bc}$ \\
\hline M achine & None & $15.0 \mathrm{a}$ & $23.7 \mathrm{de}$ & 3.60 & $0.57 \mathrm{a}$ & $0.31 \mathrm{bc}$ \\
\hline M achine & $\mathrm{M}-\mathrm{O}^{\mathrm{y}}(400 \mathrm{rpm})$ & $8.5 \mathrm{c}$ & $26.6 \mathrm{ab}$ & 3.72 & $0.51 b c$ & $0.39 a b$ \\
\hline M inimal & None & $15.2 \mathrm{a}$ & $22.4 \mathrm{e}$ & 3.52 & $0.59 \mathrm{a}$ & $0.26 \mathrm{c}$ \\
\hline M inimal & M-O (600 rpm) & $10.8 \mathrm{bc}$ & $25.2 \mathrm{bcd}$ & 3.63 & $0.55 \mathrm{ab}$ & $0.37 \mathrm{ab}$ \\
\hline
\end{tabular}

zM eans within the same column having the same letters are not significantly different at $\alpha \leq 0.05$.

yM orris-O ldridge thinning unit. 
T able 3. E ffect of leaf removal method on rot, yield, and quality of 'C hardonnay' grapes grown at White H ills Vineyard, Santa M aria, C alif, 1997. Source: Striegler and Berg, Viticulture Enology Research Center, C alifornia State U niversity, Fresno.

\begin{tabular}{|c|c|c|c|c|c|}
\hline Treatment & $\begin{array}{l}\text { Rot } \\
(\%)\end{array}$ & $\begin{array}{c}\text { Yield } \\
\text { (tons/ acre) }\end{array}$ & $\begin{array}{c}\text { Soluble } \\
\text { solids } \\
(\%)\end{array}$ & $\mathrm{pH}$ & $\begin{array}{c}\text { Tartaric } \\
\text { acid } \\
(\%)\end{array}$ \\
\hline No L eaf Removal & $26.5 a^{2}$ & 4.4 & 23.3 & 3.51 & 0.85 \\
\hline $\mathrm{H}$ and Removal & $10.6 \mathrm{~b}$ & 5.7 & 22.8 & 3.52 & 0.77 \\
\hline $\mathrm{M}-\mathrm{O}^{y}$ no hand followup & $12.4 \mathrm{~b}$ & 5.5 & 23.3 & 3.56 & 0.79 \\
\hline M-O hand followup & $16.1 \mathrm{~b}$ & 5.4 & 23.7 & 3.52 & 0.92 \\
\hline
\end{tabular}

${ }^{\mathrm{z} M}$ eans within the same column having the same letters are not significantly different at $\alpha \leq 0.05$. yM orris-O Idridge thinning unit.

also Vitis vinifera $L$. and FrenchAmerican hybrids (Vitis interspecies hybrids). The French-American hybrids are interspecific hybrids that vary a great deal in their vine characteristics. Almost all hybrids tend to be extremely fruitful. This fruitfulness is due primarily to the high number of clusters per node and the extremely fruitful basal nodes. These basal nodes are seldom, if ever, fruitful with V. labruscana and $V$. vinifera species.

$\mathrm{H}$ and thinning of F rench-A merican hybrid vineyards is conducted in the traditional manner to ensure a sustainable fruit load that produces consistently high quality fruit from these cultivars. H owever, hand thinning is expensive and one of the greatest challenges in producing these cultivars. Mechanical thinning is both economical and successful on these hybrids. M echanical removal of basal leaves in V. vinifera has successfully reduced fruit rot (Table 3 ) from $26.5 \%$ to $16.1 \%$ on 'Chardonnay' grapes at Santa M aria, C alif., in 1997. Removal of leaves by hand did not significantly reduce rot over machine removal, and the cost of hand removal was estimated at \$120/ acre (2.5 ha).

M ost premium wines produced in the world comes from $V$. vinifera grapes. Wineries pay premium prices for high quality vinifera grapes. In some regions, the crop must be limited, and leaf removal is practiced to produce a specific quality, and in others, the crop must be limited to ensure maturity due to a shortened growing season. Also, crop adjustment is used in many graperegionsof the world and is even enforced by law in some. These are expensive operations when carried out with hand labor. By mechanizing theseoperations, grape production for premium wine production should become more profitable.

\section{Conclusions}

In brambles and strawberries as well as grapes, mechanization can improve efficiency, but wise use of such mechanization requires careful adaptations to specific crops and sometimesto specific cultivars. For example, al though complete vineyard mechanization systems and methods provide the viticulturist with a wide array of tools, careful use and intelligent implementation of each of these tools must be understood for the systems to be successful. Further research and continued improvement in mechanized practices will make completely mechanized systems more efficient. Adoption of completely mechanized systems can potentially mean more reliable, more stable and more economical production of premium quality fruit that will be competitive for the local, regional, national and global markets.

\section{Literature cited}

Benedict, R.H ., J.W. Fleming, and M.D. Jones. 1968. Q uality of machine-harvested grapes. Ark. Farm Res. 17(2):10.

Benedict, R.H ., J.R. M orris, J.W. Fleming, and D.R. M cC askill. 1973. Effects of temperature on quality of mechanically harvested 'Concord' grapes. Ark. Farm Res. 22(1):2.

Booster, D.E. 1973. The mowing method of harvesting strawberries. Amer. Soc. Agr. Eng. Paper 73-109.

Booster D.E., D.E. Kirk, G.W. Varseveld, and T.B. Putnam. 1970a. M echanical harvesting and handling of strawberries for processing. Amer. Soc. Agr. Eng. Paper 70-670.

Booster D.E., G.W.V Varseveld, and T .B. Putnam. 1970b. Progress in the mechanization of strawberry harvesting. O regon State U niv. Agr. Expt. Sta. Spec. Rpt. 305.

Bourne, M .C., D .F. Splittstoesser, L.R. M attick, W.B. Robinson, J.C. Moyer, N.J. Shaulis, and E.S. Shepardson. 1963. Product quality and me- chanical grape harvesting. Proc. N .Y. State H ort. Soc., Geneva. p. 227-230.

Cattell, H. 1994. Considerations in buying a mechanical harvester. Wine East's 1994 buyer's guide to winery and vineyard equipment and supplies. p. 26-28.

Cawthon, D.L . and J.R. M orris. 1977. Yield and quality of 'C oncord' grapes as affected by pruning severity, nodes per bearing unit, training system, shoot positioning, and sampling date in Arkansas. J. Amer. Soc. H ort. Sci. 102:760-767.

Christensen, L.P. 1997. H ow do Thompson Seedless, Fiesta, and DOVine compare in new raisin vineyard planting decisions? Proc. San J oaquin Valley GrapeSymp. U niv. ofC alif, Fresno.

Christensen, P., C. Lynn, H .P. O Imo, and H .E. Studer. 1970. Mechanical harvesting of Black Corinth raisins. Calif. Agr. 24(10):4-6.

Christensen, L.P., A.N . Kasimatis, J.J. Kissler, F. J ensen, and D.A. Luvisi. 1973. M echanical harvesting of grapes for the winery. Calif Agr. Ext. Bul. AXT-403.

Crandall, P.C., C.H . Shanks, J r., and J.E. George, J r. 1966. M echanically harvesting red raspberries and removal of insects from the harvested product. Proc. Amer. Soc. H ort. Sci. 89:295-302.

Clingeleffer, P.R. and P. M ay. 1981. The swingarm trellis for Sultana grapevine management. S. Afr. J. Enol. Viticult. 2(2):37-44.

Dale, A., E.J. H anson, D.E. Yarborough, R.J. M cN icol, E.J. Stang, R. Brennan, J.R. M orris, and G.B. H ergert. 1995. M echanical harvesting of berry crops, p. 255-367. In: J. Janick (ed.). H orticultural reviews. vol. 16. Wiley, N ew York.

Denisen, E.L. and W.F. Buchele. 1967. Mechanical harvesting of strawberries. Proc. Amer. Soc. H ort. Sci. 91:267-273.

Di Ciolo, S. and M. Zoli. 1975. Strawberry mechanical harvest with a prototype experimental harvester. Riv. Ing Agrar. 6:3-8.

Fiedler, W. 1987. Entwicklung eines verfarhens der maschinellen erdbeernte und erste einsatzerfahrungen. Arch. Gartenbau. 35:379391

Gould, I.V. and J.R. Whiting. 1987. M echanization of raisin production with the Irymple trellis system. T rans. Amer. Soc. Agr. Eng. 1987. p. 5660.

H ansen, C.M ., R.L. Ledebuhr, R.L. Van Ee, and O. Friesen. 1983. Systems approach to strawberry harvest mechanization. Fruit, Nut Veg. $\mathrm{H}$ arvest $\mathrm{M}$ ech. (Amer. Soc. Agr. Eng.) 5-84:325331.

H echt, C. 1980. 1979-T he proving year of the SKH \& S harvester of strawberries in O regon. O regon State U niv. (Corvallis) Agr. Expt. St. Bul. 645. p. 239-240.

J ohnson, S.S. 1977. M echanical harvesting wine grapes. U SD A E con. Res. Serv. Agr. Econ. Rpt. 385.

Kemp, I. 1976. M echanical harvesting of strawberries. N.Z. J. Agr. 132:54, 57-58. 
L anier, M .R. and J.R. M orris. 1979. Evaluation of density separation for defining fruit maturities and maturation rates of once-over harvested muscadine grapes. J. Amer. Soc. H ort. Sci. 104:249252.

L auro, E.M . and G.B. H ergert. 1987. Evaluating the technical and economic feasibility of machine harvesting strawberries. Can. Soc. Agr. Eng. Paper 87-206.

L ucignani, M . 1979. Study and design of a new prototype of strawberry harvester working aside the row. Riv. Ing. Agar. 10:23-34

M alcolm, D. (ed.). 1993. N ew drying and harvesting process developed for raisins: Sun-M aid develops dried-on-vine process. Amer. Vineyard 2(9):4-5, 20-21.

M arshall, D.E., J.H . L evin, B.F . C argill, and R.T Whittenberger. 1972. Quality of bulk handled 'Concord' grapes. Presented at the 1972 Ann. M tg. Amer. Soc. Enol., U niv. of Calif., D avis.

M ay, P. and G.H . Kerridge. 1967. H arvest pruning of Sultana vines. Vitis 6:390-393.

M oore, J.N . 1979. Small fruit breeding-A rich heritage, a challenging future. $\mathrm{H}$ ortScience 14:333-341.

Moore, J.N. 1984. Blackberry breeding. H ortScience 19:183-185.

Morris, J.R. 1994. M echanical harvesting and vineyard mechanization. WineE ast's 1994 buyer's guide to winery and vineyard equipment and supplies. p. 4-23.

M orris, J.R. 1985. Approaches to more efficient vineyard management. H ortScience20(6):10081013.

M orris, J.R. and D.L. Cawthon. 1979. Postharvest quality of machine-harvested strawberries. J. Amer. Soc. H ort. Sci. 104:138-141.

Morris, J.R. and D.L. Cawthon. 1980a. Mechanical trimming and node adjustment of cordon-trained 'C oncord' grapevines. J. Amer. Soc. H ort. Sci. 105(3):310-313.

M orris, J R. and D .L. Cawthon. 1980b. Yield and quality response of 'C oncord grapes to training systemsand pruning severity in Arkansas. J. Amer. Soc. H ort. Sci 105(3):307-310.

M orris, J.R. and D.L. C awthon. 1981. Yield and quality responseof 'C oncord grapes(Vitislabrusca L.) to mechanized vine pruning. Amer. J. Enol. Viticult. 32:280-282.

M orris, J.R., J.W. Fleming, R.H . Benedict, and D.R. M cC askill. 1972. M aintaining juice quality of 'C oncord' grapes harvested mechanically. Ark. Farm Res. 22(1):3.

M orris, J.R., D.L. Cawthon, and J.W. Fleming. 1975. Effect of mechanical pruning on yield and quality of 'Concord grapes. Ark. Farm Res. 24(3):12.

M orris, J.R., D.L. Cawthon, G.S. N elson, and P.E. Cooper. 1978a. Effect of daminozide and ethephon on yield and quality of erect blackberries. J. Amer. Soc. H ort. Sci. 103:804-806.
M orris, J.R., G.S. N elson, A.A. Kattan, and D .L. Cawthon. 1978b. D eveloping amechanized harvesting and production system for erect blackberries. H ortScience 13(3):228-235.

M orris, J.R., A.A. Kattan, G.S. N elson, and D .L. Cawthon. 1978c. D eveloping a mechanized system for production, harvesting and handling of strawberries. H ortScience 13:413-422.

M orris, J .R., D.L. C awthon, and R.W. Buescher. 1979a. Effects of acetaldehyde on postharvest quality of mechanically harvested strawberriesfor processing. J. Amer. Soc. H ort. Sci. 104:262264.

M orris, J.R., D.L. Cawthon, and J.W. Fleming 1979b. Effects of temperature and $\mathrm{SO}_{2}$ addition on quality and postharvest behavior of mechanically harvested juice grapes in Arkansas. J. Amer. Soc. H ort. Sci. 104:166.

M orris, J.R., G.S. N elson, D.L. Cawthon, and R.W. Buescher. 1979c. A cetaldehyde effects on postharvest quality of machine-harvested strawberries. Ark. Farm Res. 28(3):10.

M orris, J.R., S.E. Spayd, D.L. Cawthon, A.A. Kattan, and G.S. N elson. 1980. Response of seven strawberry clones to hand picking prior to once-over machine harvest, p. 15-24. In: L. $M$ artin and J.R. M orris(eds.) Strawberry mechanization. O regon State U niv. Expt. Sta. Bul. 645.

Morris, J.R., D.L. Cawthon, and C.A. Sims. 1984. Long-term effects of pruning severity, nodesper bearing unit, training system and shoot positioning on yield and quality of 'Concord' grapes. J. Amer. Soc. H ort. Sci. 109(5):676683.

N elson G.S. and A.A. Kattan. 1967. A mechanical harvester for strawberries. Ark. Farm Res. 16(4):2.

N elson G.S., J.R. M orris, A.A. Kattan, and K.P. Shelby. 1978. M echanical system for harvesting and handling strawberries for processing. T rans. Amer. Soc. Agr. Eng. 19:21-26.

Nelson, G.S., J.R. Morris, and K.P. Shelby. 1979. In-plant equipment for handling machineharvested strawberries. Ark. Farm Res. 25(6):8.

O 'Brien, M . and H .E. Studer. 1977. Closed and open transport and sampling of wine grapes. Trans. Amer. Soc. Agr. Eng. 20:631.

O Imo, H .P. 1980. M echanical harvest of grapes, p. 187. In: U niv. Calif. D avis Grape and Vine Centennial Symp. Proc.

Petrucci, V.E., N . Canata, H .R. Bolin, G. Fuller, and A.E. Stafford. 1974. U se of oleic acid derivatives to accelerate drying of Thompson Seedless grapes. J. Amer. Oil Chem. Soc. 51(3):77-80.

Q uick, G. R. and E.L. D enison. 1970. A strawberry harvest mechanization system. $\mathrm{H}$ ortScience 5:110-151

Rosati, P. 1980. M echanization of the Italian strawberry industry. O regon State U niv. (Corvallis) Agr. Expt. Sta. Bul. 645. p. 66-69

Shaw, I . 1986. D evelopment of specialized trellis drying systems. $\mathrm{H}$ anging cane, p. 93-94. In: I. Ballantyne and I. M acrae (eds.). Trellis drying and mechanical harvesting of grapes. Dept. of Agr. Rural Affairs, Conf. Proc. Ser. 7

Shepardson, E.S. and W.F. M iller. 1962. Progress report: M echanical grapeharvester research. N.Y. State Agr. Expt. Sta. (Geneva) Res. Rpt.

Shepardson, E.S., N.J. Shaulis, and J.C. M oyers. 1969. M echanical harvesting of grape varieties grown in N ew York State, p. 571. In: B. Cargill and A. Rossmiller (eds.). Fruit and vegetable harvest mechanization. Rural $\mathrm{M}$ anpower Center, $M$ ich. State U niv., East L ansing.

Shikaze, A. and D.R. N yborg. 1973. M echanical strawberry harvester trials. Can. Soc. Agr. Eng. Paper 73-320.

Sims, C.A. and J.R. M orris. 1982. Effects of cultivar, irrigation, and ethephon on the yield, harvest distribution, and quality of machineharvested blackberries. J. Amer. Soc. H ort. Sci. 107:542-547.

Sistrunk, W.A. and J.R. M orris. 1978. Storage stability of strawberry products manufactured from mechanically harvested strawberries. J. Amer. Soc. H ort. Sci. 103:616-620.

Spayd, S.E. and J.R. M orris. 1981. Physical and chemical characteristics of puree from once-over harvested strawberries. J. Amer. Soc. H ort. Sci. 106:105-109.

Striegler, R.K., J.R. M orris, and G.T . Berg. 1996. Raisin production and processing, p. 235-265. In: L. Somogyi (ed.) Processing fruits: Science and technology. vol 2. Technomic Publ., Lancaster, $\mathrm{Pa}$.

Studer, H .E. and H .P. O Imo. 1969. M echanical harvesting of grapes in California: Cultural practicesand machines, p. 611-625. In B. C argill and A. Rossmiller (eds.). Fruit and vegetable mechanization. Rural $\mathrm{M}$ anpower $\mathrm{Center}, \mathrm{M}$ ich. State U niv., East Lansing.

Studer, H .E. and H .P. O Imo. 1971. The severed cane technique and its application to mechanical harvesting of raisin grapes. Trans. Amer. Soc. Agr. Eng. 14:38.

Studer, H .E. and H .P. O Imo. 1973. Vine-drying of Thompson Seedless grapes. Calif. Raisin Adv. Board Raisin Res. Rpt. 1973. p. 960-970.

Studer, H.E. and H .P. O Imo. 1974. Parameters affecting the quality of machine-harvest raisins. Trans. Amer. Soc. Agr. Eng. 17:783.

Swinkles, P.M . and R.A. M urray. 1991. Development of the Bragg strawberry harvester, p. 266 In: A. D ale and J.J. L uby (eds.). The strawberry into the $21^{\text {st }}$ century. Timber Press, Portland, Ore.

Thuesen, A. 1988. M askinhost af industrijordbaer Gron Viden 141, D enmark

Whittenberger, R.T. D.E. M arshall, J.H . L evin, and B.F. Cargill. 1971. Bulk handling of 'C oncord' grapes for processing: Q uality evaluation. Presented at Annu. M tg. Amer. Soc. Agr. Eng., St. Joseph, M ich. 